\title{
The thermal decomposition of the benzyl radical in a heated micro-reactor. I. Experimental findings
}

\author{
Grant T. Buckingham, ${ }^{1,2}$ Thomas K. Ormond, ${ }^{1,2}$ Jessica P. Porterfield, ${ }^{1}$ Patrick Hemberger, ${ }^{3}$ \\ Oleg Kostko, ${ }^{4}$ Musahid Ahmed, ${ }^{4}$ David J. Robichaud, ${ }^{2}$ Mark R. Nimlos, ${ }^{2}$ John W. Daily, ${ }^{5}$ \\ and G. Barney Ellison ${ }^{1}$ \\ ${ }^{1}$ Department of Chemistry and Biochemistry, University of Colorado, Boulder, Colorado 80309-0215, USA \\ ${ }^{2}$ National Renewable Energy Laboratory, 15013 Denver West Parkway, Golden, Colorado 80401, USA \\ ${ }^{3}$ Molecular Dynamics Group, Paul Scherrer Institut, CH-5232 Villigen-PSI, Switzerland \\ ${ }^{4}$ Chemical Sciences Division, Lawrence Berkeley National Laboratories, Berkeley, California 94720, USA \\ ${ }^{5}$ Department of Mechanical Engineering, Center for Combustion and Environmental Research, \\ University of Colorado, Boulder, Colorado 80309-0427, USA
}

(Received 11 November 2014; accepted 7 January 2015; published online 29 January 2015)

\begin{abstract}
The pyrolysis of the benzyl radical has been studied in a set of heated micro-reactors. A combination of photoionization mass spectrometry (PIMS) and matrix isolation infrared (IR) spectroscopy has been used to identify the decomposition products. Both benzyl bromide and ethyl benzene have been used as precursors of the parent species, $\mathrm{C}_{6} \mathrm{H}_{5} \mathrm{CH}_{2}$, as well as a set of isotopically labeled radicals: $\mathrm{C}_{6} \mathrm{H}_{5} \mathrm{CD}_{2}, \mathrm{C}_{6} \mathrm{D}_{5} \mathrm{CH}_{2}$, and $\mathrm{C}_{6} \mathrm{H}_{5}{ }^{13} \mathrm{CH}_{2}$. The combination of PIMS and IR spectroscopy has been used to identify the earliest pyrolysis products from benzyl radical as: $\mathrm{C}_{5} \mathrm{H}_{4}=\mathrm{C}_{2}=\mathrm{CH}_{2}, \mathrm{H}$ atom, $\mathrm{C}_{5} \mathrm{H}_{4}-\mathrm{C} \equiv \mathrm{CH}, \mathrm{C}_{5} \mathrm{H}_{5}, \mathrm{HCCCH}_{2}$, and $\mathrm{HC} \equiv \mathrm{CH}$. Pyrolysis of the $\mathrm{C}_{6} \mathrm{H}_{5} \mathrm{CD}_{2}, \mathrm{C}_{6} \mathrm{D}_{5} \mathrm{CH}_{2}$, and $\mathrm{C}_{6} \mathrm{H}_{5}{ }^{13} \mathrm{CH}_{2}$ benzyl radicals produces a set of methyl radicals, cyclopentadienyl radicals, and benzynes that are not predicted by a fulvenallene pathway. Explicit PIMS searches for the cycloheptatrienyl radical were unsuccessful, there is no evidence for the isomerization of benzyl and cycloheptatrienyl radicals: $\mathrm{C}_{6} \mathrm{H}_{5} \mathrm{CH}_{2} \leftrightharpoons \mathrm{C}_{7} \mathrm{H}_{7}$. These labeling studies suggest that there must be other thermal decomposition routes for the $\mathrm{C}_{6} \mathrm{H}_{5} \mathrm{CH}_{2}$ radical that differ from the fulvenallene pathway. ( 2015 AIP Publishing LLC. [http://dx.doi.org/10.1063/1.4906156]
\end{abstract}

\section{INTRODUCTION}

The benzyl radical is a fundamental molecule in chemistry not only because of its relevance in combustion and atmospheric chemistry, but also due to its importance as a resonance-stabilized radical. Benzyl radical, $\mathrm{C}_{6} \mathrm{H}_{5} \mathrm{CH}_{2}$, is a long-lived combustion species and is an important sootprecursor. Reaction with oxygen is quite slow because the resulting adduct, $\mathrm{C}_{6} \mathrm{H}_{5} \mathrm{CH}_{2} \mathrm{OO}$, is not very stable: $\mathrm{C}_{6} \mathrm{H}_{5} \mathrm{CH}_{2}+$ $\mathrm{O}_{2} \leftrightharpoons \mathrm{C}_{6} \mathrm{H}_{5} \mathrm{CH}_{2} \mathrm{OO}$. Consequently, the oxidation of $\mathrm{C}_{6} \mathrm{H}_{5} \mathrm{CH}_{2}$ is sluggish, which leaves benzyl radicals available to contribute to soot formation.

This paper is focused on the thermal decomposition pathways of the benzyl radical itself. Pyrolysis of benzyl bromide and ethyl benzene in a set of heated micro-reactors produced samples of $\mathrm{C}_{6} \mathrm{H}_{5} \mathrm{CH}_{2}$ that were observed to decompose to a complex set of atoms, radicals, and metastables. A combination of photoionization mass spectroscopy (PIMS) and matrix infrared (IR) spectroscopy has been used to identify the initial decomposition products.

In 1948, pioneering shock tube measurements ${ }^{1}$ decomposed the aromatics toluene and xylene. About 30 years later, a set of experiments were reported ${ }^{2}$ in which toluene was decomposed in a Knudsen cell. The Knudsen cell was heated to $2100 \mathrm{~K}$ and coupled to an electron impact $(E I)$ mass spectrometer. The resulting mass spectra identified the presence of $\mathrm{C}_{2} \mathrm{H}_{2}, \mathrm{C}_{3} \mathrm{H}_{3}, \mathrm{C}_{4} \mathrm{H}_{2}, \mathrm{C}_{4} \mathrm{H}_{4}, \mathrm{C}_{5} \mathrm{H}_{5}$, and $\mathrm{C}_{6} \mathrm{H}_{6}$ and all species were assigned as thermal decomposition products of $\mathrm{C}_{6} \mathrm{H}_{5} \mathrm{CH}_{2}$. Subsequent shock tube studies were carried out on a variety of aromatic precursors and the decomposition products were monitored by vacuum ultraviolet (VUV) absorption spectroscopy. ${ }^{3-5}$ It was demonstrated ${ }^{5}$ that ethylbenzene decomposes to the radical pair, $\left(\mathrm{C}_{6} \mathrm{H}_{5} \mathrm{CH}_{2}\right.$ and $\left.\mathrm{CH}_{3}\right)$ and not to $\left(\mathrm{C}_{6} \mathrm{H}_{5} \mathrm{CHCH}_{3}\right.$ plus $\left.\mathrm{H}\right)$. In 1986, Rao and Skinner ${ }^{6}$ presented the results of shock tube measurements for the decomposition of ethylbenzene- $\mathrm{d}_{10}$ and ethyl- $\alpha, \alpha-\mathrm{d}_{2}$-benzene in argon behind incident shock waves at temperatures of 1430$1740 \mathrm{~K}$. Progress of the reaction was followed by analysis for $\mathrm{H}$ and $\mathrm{D}$ atoms by atomic resonance absorption spectroscopy (ARAS). ARAS demonstrated that benzyl radicals decompose to hydrogen atoms and other unknown products. Benson made the imaginative suggestion ${ }^{6}$ that the pyrolysis of benzyl radical proceeded by rearrangement to a bicyclic species followed by fragmentation to fulvenallene $\left(\mathrm{C}_{5} \mathrm{H}_{4}=\mathrm{C}=\mathrm{CH}_{2}\right)$ and $\mathrm{H}$ atom. Fulvenallene could further decompose to the fulvenallenyl radical, $\mathrm{C}_{5} \mathrm{H}_{4}-\mathrm{C} \equiv \mathrm{CH}$. Rather than Benson's stepwise rearrangement to fulvenallene, benzyl could suffer a concerted fragmentation to the cyclopentadienyl radical and vinylidene. Vinylidene $\left(\mathrm{CH}_{2}=\mathrm{C}\right)$ is known ${ }^{7,8}$ to rapidly isomerize to $\mathrm{HC} \equiv \mathrm{CH}$. Finally, classical organic chemistry might expect rearrangement of benzyl to the cycloheptatrienyl radical; subsequent $\mathrm{C}_{7} \mathrm{H}_{7}$ fragmentation could directly provide $\mathrm{HC} \equiv \mathrm{CH}$ and $\mathrm{C}_{5} \mathrm{H}_{5}$. These suggestions are outlined in Fig. 1. 
Possible Pathways for Benzyl Radical Thermal Decomposition

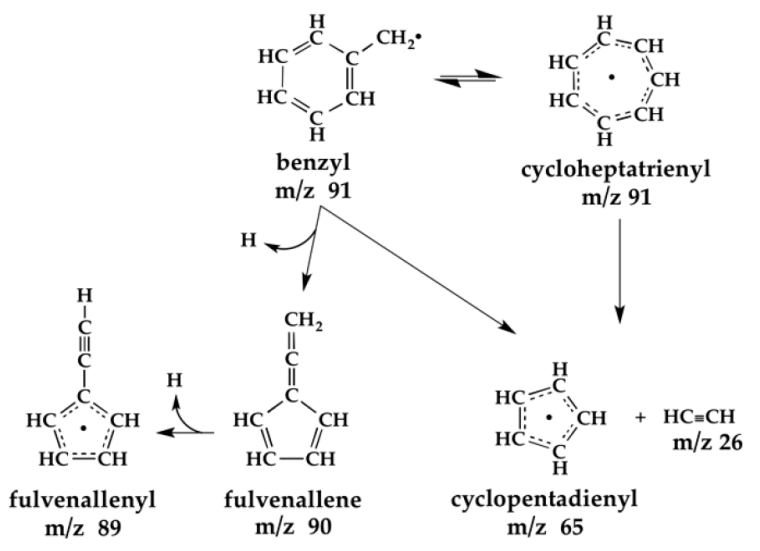

FIG. 1. Benzyl radical is proposed to decompose not through direct bond breakage but through isomerization(s) reaction. Loss of one hydrogen atom can lead to fulvenallene $\left(\mathrm{C}_{5} \mathrm{H}_{4}=\mathrm{C}=\mathrm{CH}_{2}, \mathrm{~m} / \mathrm{z} 90\right)$ and a second hydrogen atom loss would produce the fulvenallenyl radical $\left(\mathrm{C}_{5} \mathrm{H}_{4}-\mathrm{C} \equiv \mathrm{XH}, \mathrm{m} / \mathrm{z} 89\right)$. Isomerization to cycloheptatrienyl radical has also been proposed.

Decomposition of benzyl radical has also been investigated by photochemistry. Molecular beams of either toluene or cycloheptatriene were irradiated with UV light to form "hot" benzyl radicals that underwent immediate unimolecular decomposition. Fragmentation products were detected using EI mass spectrometry ${ }^{9}$ and the first direct detection of $\mathrm{C}_{7} \mathrm{H}_{6}$ (m/z 90) was reported as the product of $\mathrm{C}_{7} \mathrm{H}_{7} \rightarrow \mathrm{C}_{7} \mathrm{H}_{6}+\mathrm{H}$.

Further experiments were reported to pursue Benson's suggested mechansism. ${ }^{10,11}$ In the work of Jones et al. ${ }^{12}$ shock tube measurements of the decomposition of benzyl bromide were coupled with computational studies to suggest multiple benzyl radical decomposition mechanisms. Four mechanism were proposed: (1) formation of the norbornadienyl radical followed by $\mathrm{C}_{5} \mathrm{H}_{5}+\mathrm{HCCH}$ formation, (2) ring opening leading to linear $\mathrm{C}_{7} \mathrm{H}_{6}+\mathrm{H}$ and further fragmentation, (3) Benson's isomerization to the bicyclic intermediate, 6-methylenebicyclo[3.1.0]hex-3en-2-yl radical that subsequently decomposes to the fulvenallenyl radical $\left(\mathrm{C}_{5} \mathrm{H}_{4}-\mathrm{C} \equiv \mathrm{CH}\right)+\mathrm{H}$ atom or $\mathrm{C}_{5} \mathrm{H}_{5}+\mathrm{HCCH}$, and (4) isomerization to a seven-membered ring followed by formation of $\mathrm{C}_{5} \mathrm{H}_{5}+\mathrm{HCCH}$. Further computational studies have reported ${ }^{13}$ fulvenallene formation as the major decomposition route for benzyl radical. Density functional theory (DFT) calculations ${ }^{14}$ found that hydrogen addition to fulvenallene would result in $\mathrm{C}_{5} \mathrm{H}_{5}+\mathrm{C}_{2} \mathrm{H}_{2}$. Recently, there has been extensive work ${ }^{15-19}$ performed on potential energy surfaces for each of the species $\mathrm{C}_{7} \mathrm{H}_{7}, \mathrm{C}_{7} \mathrm{H}_{6}$, and $\mathrm{C}_{7} \mathrm{H}_{5}$ and their interplay during benzyl radical decomposition. Because of their likely importance during the decomposition of benzyl, both fulvenallene and fulvenallenyl radicals, ${ }^{20,21}$ as well as the cycloheptatrienyl radical ${ }^{22}$ have been detected and identified by PIMS.

To explore the thermal decomposition of the benzyl radical, we have prepared $\mathrm{C}_{6} \mathrm{H}_{5} \mathrm{CH}_{2}$ from both ethylbenzene and benzyl bromide in a heated micro-reactor. By increasing the temperature of the reactor, pyrolysis of the benzyl radical was observed. Our goal is to identify the nascent fragmentation products: $\mathrm{C}_{6} \mathrm{H}_{5} \mathrm{CH}_{2}(+\mathrm{M}) \rightarrow$ products.

Over the last decade, we have used a set of micro-reactors to examine the pyrolysis of complex organic molecules. These resistively heated silicon carbide $(\mathrm{SiC})$ reactors are typically $0.5-1 \mathrm{~mm}$ inner diameter and are $2-3 \mathrm{~cm}$ long. Target molecules are delivered to the reactor as dilute mixtures (typically $0.1 \%$ or less) in $\mathrm{He}$, Ar, or Ne buffer gases with entrance pressures of 200-300 Torr. The micro-reactors can be operated in either pulsed or continuous flow $(\mathrm{CW})$ modes and are heated to temperatures up to $1800 \mathrm{~K}$. Residence times in the microreactors are in the range of $25-150 \mu \mathrm{s}$. Gases exit the hot micro-reactors into a vacuum of $10^{-6}$ Torr where all reactions are quenched. A combination of PIMS, matrix isolation infrared spectroscopy, resonance-enhanced multiphoton ionization spectroscopy, and microwave spectroscopy has been used to identify all the decomposition products. This package of spectroscopies is very powerful and enables identification of all products (atoms, radicals, and metastables) that are formed in the first $100 \mu$ s of complex fuel pyrolysis. ${ }^{23-29}$ The goal of the present study is to produce clean samples of benzyl and to observe the temperature-dependent decomposition of the radical. With care, the set of micro-reactors can be used to confirm the fragmentation products from benzyl radical and indicate which mechanism(s) are activated first.

The experimental thermochemical and electronic properties of benzyl radical $\left(\mathrm{C}_{6} \mathrm{H}_{5} \mathrm{CH}_{2}, \tilde{\chi}^{2} \mathrm{~B}_{1}\right)$ have been compiled in Table I, alongside data for its isomer, the cycloheptatrienyl radical $\left(\mathrm{C}_{7} \mathrm{H}_{7} \tilde{\chi}^{2} \mathrm{E}_{2}{ }^{\prime \prime}\right)$. Experimental information is included for three precursors of benzyl radical: toluene, benzyl bromide, and ethylbenzene.

\section{EXPERIMENTAL}

The thermal decomposition of benzyl radical is studied by entraining a dilute sample of precursor in helium, neon, or argon. The precursors used in this study are benzyl bromide $\left(\mathrm{C}_{6} \mathrm{H}_{5} \mathrm{CH}_{2} \mathrm{Br}\right)$ and ethylbenzene $\left(\mathrm{C}_{6} \mathrm{H}_{5} \mathrm{CH}_{2} \mathrm{CH}_{3}\right)$. Both precursors are available from Sigma-Aldrich with reported purities of $98 \%$ and $99 \%$, respectively, and are liquid at room temperature. Additionally, multiple isotopomers have been examined including $\mathrm{C}_{6} \mathrm{H}_{5} \mathrm{CD}_{2} \mathrm{Br}, \mathrm{C}_{6} \mathrm{D}_{5} \mathrm{CH}_{2} \mathrm{Br}, \mathrm{C}_{6} \mathrm{H}_{5} \mathrm{CD}_{2} \mathrm{CD}_{3}$, $\mathrm{C}_{6} \mathrm{D}_{5} \mathrm{CH}_{2} \mathrm{CH}_{3}$, and $\mathrm{C}_{6} \mathrm{H}_{5}{ }^{13} \mathrm{CH}_{2} \mathrm{CH}_{3}$, all of which were purchased from $\mathrm{CDN}$ Isotopes, with a reported isotopic enrichment of $98 \%$ for the deuterium isotopomers and $99 \%$ for the ${ }^{13} \mathrm{C}$ isotopomer. Due to the significant implications that result from decomposition of $\mathrm{C}_{6} \mathrm{H}_{5}{ }^{13} \mathrm{CH}_{2} \mathrm{CH}_{3},{ }^{13} \mathrm{C}$ NMR was used to confirm that the $\alpha$-carbon is $98.9 \% \pm 0.1 \%{ }^{13} \mathrm{C}$. The vapor pressure of ethylbenzene is large enough to prepare static sample volumes of between $0.1 \%$ and $0.01 \%$ ethylbenzene in up to 1500 Torr of noble gas cylinders. Benzyl bromide, however, requires flowing pure carrier gas over a sample of liquid precursor. The benzyl bromide sample was never heated so as to avoid higher $\mathrm{C}_{6} \mathrm{H}_{5} \mathrm{CH}_{2} \mathrm{Br}$ concentrations that would trigger bimolecular chemistry. The ratio of the vapor pressure at the sample temperature to the backing pressure was used to approximate the concentration of benzyl bromide in the beam. A careful dilution study with ethylbenzene shows that as concentrations were lowered from $0.1 \%$ to $0.02 \%$, some peaks in the mass spectra lost signal intensity more rapidly than other peaks, thus indicating their higher order dependence on concentration. As a result, all of the PIMS peaks discussed 
TABLE I. Experimental properties of benzyl and cycloheptatrienyl radicals.

\begin{tabular}{|c|c|c|}
\hline $\operatorname{IE}\left(\mathrm{C}_{6} \mathrm{H}_{5} \mathrm{CH}_{2}, \tilde{\chi}^{2} \mathrm{~B}_{1}\right)$ & $7.2487 \pm 0.0006 \mathrm{eV}$ & References 55 and 56 \\
\hline$\Delta_{\mathrm{f}} \mathrm{H}_{298}\left(\mathrm{C}_{6} \mathrm{H}_{5} \mathrm{CH}_{2}, \tilde{\chi}^{2} \mathrm{~B}_{1}\right)$ & $\begin{array}{l}49.7 \pm 0.6 \mathrm{kcal} \mathrm{mol}^{-1} \\
\left(208 \pm 3 \mathrm{~kJ} \mathrm{~mol}^{-1}\right)\end{array}$ & Reference 57 \\
\hline$\Delta_{\mathrm{rxn}} \mathrm{H}_{298}\left(\mathrm{C}_{6} \mathrm{H}_{5} \mathrm{CH}_{2} \rightarrow \mathrm{HCCH}+\mathrm{C}_{5} \mathrm{H}_{5}\right)$ & $\begin{aligned} 68 & \pm 2 \mathrm{kcal} \mathrm{mol}^{-1} \\
(284 & \left. \pm 6 \mathrm{~kJ} \mathrm{~mol}^{-1}\right)\end{aligned}$ & This work \\
\hline$\Delta_{\text {acid }} H_{298}\left(\mathrm{C}_{6} \mathrm{H}_{5} \mathrm{CH}_{2}-\mathrm{H}\right)$ & $\begin{array}{l}382.3 \pm 0.5 \mathrm{kcal} \mathrm{mol}^{-1} \\
\left(1600 \pm 2 \mathrm{~kJ} \mathrm{~mol}^{-1}\right)\end{array}$ & Reference 58 \\
\hline$E A\left(\mathrm{C}_{6} \mathrm{H}_{5} \mathrm{CH}_{2}, \tilde{\chi}^{2} \mathrm{~B}_{1}\right)$ & $0.912 \pm 0.006 \mathrm{eV}$ & Reference 59 \\
\hline$\Delta_{\text {isomerization }} H_{298}\left(\mathrm{C}_{6} \mathrm{H}_{5} \mathrm{CH}_{2} \tilde{\chi}^{2} \mathrm{~B}_{1} \rightarrow \mathrm{C}_{7} \mathrm{H}_{7} \tilde{\chi}^{2} \mathrm{E}_{2}{ }^{\prime \prime}\right)$ & $\begin{aligned} 15.3 & \pm 0.9 \mathrm{kcal} \mathrm{mol}^{-1} \\
(64 & \left. \pm 4 \mathrm{~kJ} \mathrm{~mol}^{-1}\right)\end{aligned}$ & This work \\
\hline$I E\left(\mathrm{C}_{7} \mathrm{H}_{7}, \tilde{\chi}^{2} \mathrm{E}_{2}^{\prime \prime}\right)$ & $6.221 \pm 0.006 \mathrm{eV}$ & References 22 and 60 \\
\hline$\Delta_{\mathrm{f}} H_{298}\left(\mathrm{C}_{7} \mathrm{H}_{7} \tilde{\chi}^{2} \mathrm{E}_{2}^{\prime \prime}\right)$ & $\begin{array}{l}65.0 \pm 0.7 \mathrm{kcal} \mathrm{mol}^{-1} \\
\left(272 \pm 3 \mathrm{~kJ} \mathrm{~mol}^{-1}\right)\end{array}$ & Reference 57 \\
\hline$\Delta_{\mathrm{rxn}} \mathrm{H}_{298}\left(\mathrm{C}_{7} \mathrm{H}_{7} \rightarrow \mathrm{HCCH}+\mathrm{C}_{5} \mathrm{H}_{5}\right)$ & $\begin{aligned} 53 & \pm 2 \mathrm{kcal} \mathrm{mol}^{-1} \\
(220 & \left. \pm 7 \mathrm{~kJ} \mathrm{~mol}^{-1}\right)\end{aligned}$ & This work \\
\hline$A E\left(\mathrm{C}_{7} \mathrm{H}_{8} \rightarrow \mathrm{C}_{7} \mathrm{H}_{7}^{+}+\mathrm{H}\right)$ & $9.36 \pm 0.02 \mathrm{eV}$ & Reference 61 \\
\hline$\Delta_{\mathrm{f}} \mathrm{H}_{298}\left(\mathrm{C}_{5} \mathrm{H}_{5}, \tilde{\chi}^{2} \mathrm{E}_{1}{ }^{\prime \prime}\right)$ & $\begin{array}{c}63 \pm 1 \mathrm{kcal} \mathrm{mol}^{-1} \\
\left(264 \pm 6 \mathrm{~kJ} \mathrm{~mol}^{-1}\right)\end{array}$ & Reference 62 \\
\hline $\mathrm{DH}_{298}\left(\mathrm{C}_{6} \mathrm{H}_{5} \mathrm{CH}-\mathrm{H}\right)$ & $\begin{array}{c}106 \pm 4 \mathrm{kcal} \mathrm{mol}^{-1} \\
\left(444 \pm 15 \mathrm{~kJ} \mathrm{~mol}^{-1}\right)\end{array}$ & References 63 and 64 \\
\hline$D_{298}\left(\mathrm{C}_{6} \mathrm{H}_{5}-\mathrm{CH}_{2}\right)$ & $\begin{aligned} 124.3 & \pm 0.9 \mathrm{kcal} \mathrm{mol}^{-1} \\
(520 & \left. \pm 4 \mathrm{~kJ} \mathrm{~mol}^{-1}\right)\end{aligned}$ & Reference 57 \\
\hline $\mathrm{DH}_{298}\left(\mathrm{C}_{6} \mathrm{H}_{5} \mathrm{CH}_{2}-\mathrm{H}\right)$ & $\begin{array}{l}89.8 \pm 0.6 \mathrm{kcal} \mathrm{mol}^{-1} \\
\left(276 \pm 3 \mathrm{~kJ} \mathrm{~mol}^{-1}\right)\end{array}$ & References 58 \\
\hline $\mathrm{DH}_{298}\left(\mathrm{C}_{7} \mathrm{H}_{7}-\mathrm{H}\right)$ & $\begin{array}{l}73.9 \pm 0.5 \mathrm{kcal} \mathrm{mol}^{-1} \\
\left(220 \pm 7 \mathrm{~kJ} \mathrm{~mol}^{-1}\right)\end{array}$ & Reference 61 \\
\hline $\mathrm{DH}_{298}\left(\mathrm{C}_{6} \mathrm{H}_{5} \mathrm{CH}_{2}-\mathrm{Br}\right)$ & $\begin{array}{c}61 \pm 1 \mathrm{kcal} \mathrm{mol}^{-1} \\
\left(220 \pm 7 \mathrm{~kJ} \mathrm{~mol}^{-1}\right)\end{array}$ & Reference 57 \\
\hline $\mathrm{DH}_{298}\left(\mathrm{C}_{6} \mathrm{H}_{5} \mathrm{CH}_{2}-\mathrm{CH}_{3}\right)$ & $\begin{array}{l}77.6 \pm 0.7 \mathrm{kcal} \mathrm{mol}^{-1} \\
\left(325 \pm 3 \mathrm{~kJ} \mathrm{~mol}^{-1}\right)\end{array}$ & Reference 57 \\
\hline $\mathrm{DH}_{298}\left(\mathrm{C}_{6} \mathrm{H}_{5}-\mathrm{CH}_{2} \mathrm{CH}_{3}\right)$ & $\begin{aligned} 102.3 & \pm 0.7 \mathrm{kcal} \mathrm{mol}^{-1} \\
(428 & \left. \pm 3 \mathrm{~kJ} \mathrm{~mol}^{-1}\right)\end{aligned}$ & Reference 57 \\
\hline \multicolumn{3}{|c|}{ Important ionization energies } \\
\hline $\mathrm{CH}_{3}$ & $9.8380 \pm 0.0004 \mathrm{eV}$ & Reference 65 \\
\hline $\mathrm{HC} \equiv \mathrm{CH}$ & $11.40081 \pm 0.00001 \mathrm{eV}$ & Reference 66 \\
\hline $\mathrm{HCCCH}_{2}$ & $8.7006 \pm 0.0002 \mathrm{eV}$ & Reference 67 \\
\hline $\mathrm{C}_{5} \mathrm{H}_{5}$ & $8.4268 \pm 0.0005 \mathrm{eV}$ & Reference 48 \\
\hline$o-\mathrm{C}_{6} \mathrm{H}_{4}$ & $9.03 \pm 0.05 \mathrm{eV}$ & Reference 47 \\
\hline $\mathrm{C}_{6} \mathrm{H}_{5}$ & $8.32 \pm 0.04 \mathrm{eV}$ & Reference 68 \\
\hline $\mathrm{C}_{5} \mathrm{H}_{4}-\mathrm{C} \equiv \mathrm{CH}$ & $8.19 \pm 0.02 \mathrm{eV}$ & Reference 20 \\
\hline $\mathrm{C}_{5} \mathrm{H}_{4}=\mathrm{C}=\mathrm{CH}_{2}$ & $8.22 \pm 0.01 \mathrm{eV}$ & Reference 20 \\
\hline $\mathrm{C}_{6} \mathrm{H}_{5} \mathrm{CH}_{2}$ & $7.2487 \pm 0.0006 \mathrm{eV}$ & References 55 and 56 \\
\hline $\mathrm{C}_{7} \mathrm{H}_{7}$ & $6.221 \pm 0.006 \mathrm{eV}$ & References 22 and 60 \\
\hline $\mathrm{C}_{6} \mathrm{H}_{5} \mathrm{CH}_{2} \mathrm{CH}_{3}$ & $8.7734 \pm 0.0007 \mathrm{eV}$ & Reference 69 \\
\hline $\mathrm{C}_{6} \mathrm{H}_{5} \mathrm{CH}_{2} \mathrm{Br}$ & $8.990 \pm 0.015 \mathrm{eV}$ & Reference 70 \\
\hline
\end{tabular}

herein are believed to be solely a result of unimolecular decomposition.

Benzyl radical, its precursors, and its fragmentation products are detected by means of PIMS and IR spectroscopy. We have carried out $118.2 \mathrm{~nm}$ PIMS with a pulsed microreactor as well as synchrotron-based PIMS with continuous flow micro-reactors at the Lawrence Berkeley National Lab's (LBNL) Advanced Light Source (ALS) in Berkeley, CA, USA and the Swiss Light Source (SLS) at the Paul Scherrer Institute in Villigen, Switzerland.

PIMS with a pulsed micro-reactor ${ }^{30}$ combines the 9th harmonic of a Nd:YAG laser (118.2 nm or $10.487 \mathrm{eV})$. The laser is synchronized to a Parker general pulsed valve backed by a helium-hydrocarbon mixture. The pulsed valve operates at $10 \mathrm{~Hz}$ and is open for about $1 \mathrm{~ms}$. A skimmer is placed about $1 \mathrm{~cm}$ from the exit of the $\mathrm{SiC}$ reactor to select only the component of the expansion traveling in the longitudinal direction with respect to the reactor tube. The internally frequencytripled output of a Nd:YAG laser is directed into a cell that is pressurized to 150 Torr with a 10:1 argon:xenon mixture. This mixture is optimized to promote sum frequency generation that creates $118.2 \mathrm{~nm}$ VUV photons, which have sufficient energy to ionize most hydrocarbons molecules. Generation of 118.2 $\mathrm{nm}$ photons by $\mathrm{Xe} / \mathrm{Ar}$ tripling cells has been studied at great length. ${ }^{31}$ Use of $30 \mathrm{~mJ}$ pulse ${ }^{-1}$ power at $355 \mathrm{~nm}$ from the YAG laser and the established tripling efficiency of $1 \times 10^{-5}$ in pure xenon $^{32,33}$ as well as the transmission efficiency of the $\mathrm{MgF}_{2}$ lens, we expect to produce roughly $30 \mathrm{~nJ}$ pulse ${ }^{-1}$ at 
$118.2 \mathrm{~nm}$ light. This VUV laser light is directed into a vacuum chamber maintained at $10^{-7}$ Torr by a $1200 \mathrm{~L} / \mathrm{s}$ Pfieffer TPU $1201 \mathrm{P}$ turbomolecular pump and is then intersected with the skimmed output of the supersonic expansion. After ionization, the molecules in the expansion are accelerated into a Jordan reflectron time of flight spectrometer with an MCP detector producing PIMS spectra at $10.487 \mathrm{eV}$.

Other experiments employ a tunable ionization source that is used with a set of continuous flow micro-reactors to measure photoionization efficiency (PIE) curves. These PIMS experiments were conducted at the Advanced Light Source using the beamline's 9.0.2 molecular beam end-station. The gas mixture of product molecules entrained in helium emerging from the hot micro-reactor is formed into a molecular beam. The skimmed molecular beam is intersected with tunable synchrotron light and the nascent ions are detected in a Jordan reflectron time of flight apparatus. Utilization of pseudo-CW ionizing radiation requires that voltages on the repeller plate be pulsed to allow discrete data acquisition. The ALS synchrotron does not easily permit scans below $7.4 \mathrm{eV}$ so in order to distinguish the isomers, benzyl $(7.2 \mathrm{eV})$ and cycloheptatrienyl radicals $(6.2 \mathrm{eV})$, tunable light down to 6 $\mathrm{eV}$ was required. These photon energies are available at the Swiss Light Source, where tunable synchrotron light extends to energies as low as $6 \mathrm{eV}$. During the SLS experiments, ${ }^{34} \mathrm{a}$ continuous stream of Ar and precursor was expanded through a micro-reactor forming a molecular beam, which was skimmed. The products were detected applying imaging photoelectron photoion coincidence (iPEPICO) techniques. ${ }^{35}$

Matrix isolation Fourier transform infrared spectroscopy is a complimentary detection method performed to help identify individual isomers present at the exit of the reactor. A similar pulse valve and tubular reactor assembly is coupled to a helium compressor-cooled cesium iodide (CsI) window that is enclosed and pumped to $10^{-6}$ Torr during pulse valve operation. Gas mixtures consist of dilute samples of molecular precursor entrained in neon. Neon is used rather than argon because its smaller atomic radius and lower electronic polarizability have been shown to create inert solid matrices that have smaller perturbations than comparable matrices using argon. Gas mixtures pulsed through the heated reactor are then directed towards the CsI window that is maintained at $5.4 \mathrm{~K}$. Gas is pulsed for $1-2 \mathrm{~h}$ with a pulse valve opening time set to $400 \mu$ s and a repetition rate of roughly $10 \mathrm{~Hz}$. Repetition rate and opening time are tuned to maintain a consistent dose rate as measured by upstream pressure decrease over time. After dosing is completed, the pulse valve assembly can be rotated out of the way to allow the CsI window to be lowered into the beampath of a commercial FTIR, where between 200 and 1000 scans can be averaged to achieve a single composite absorbance spectrum from 400 to $4000 \mathrm{~cm}^{-1}$ with $0.25 \mathrm{~cm}^{-1}$ resolution. Spectra taken in a solid neon matrix can then be compared directly to published neon matrix spectra or carefully assigned using similar spectra taken in argon matrices or gas phase to allow vibrational assignments. The band origin assignments in neon matrices show shifts from the gas-phase values of around $5 \mathrm{~cm}^{-1}$, while argon matrix assignments often have shifts on the scale of $10 \mathrm{~cm}^{-1}$. A complete list of vibrational assignments for molecules detected during the decomposition of benzyl radical (which was prepared using ethylbenzene as the precursor) is included in the supplementary material. ${ }^{36}$

The micro-reactor assembly used for pyrolysis is described in more detail elsewhere ${ }^{30,37-41}$ and consists of a $0.6 \mathrm{~mm}$ or $1 \mathrm{~mm}$ inner diameter $\mathrm{SiC}$ tubular reactor that can be resistively heated up to $1800 \mathrm{~K}$. Carbon discs are fitted to the outer diameter of the reactor approximately $1 \mathrm{~cm}$ apart and these form the contact points for the electrical circuit used to resistively heat the reactor. A Type $\mathrm{C}$ thermocouple with 0.005 " diameter wires is tightly attached to the $\mathrm{SiC}$ reactor between the two electrical contacts so that the surface temperature can be monitored directly. Backing pressures and downstream pressures vary between experiments. Table II is provided to summarize the conditions across all experiments performed in this work.

Recent computational fluid dynamics (CFD) simulations ${ }^{42}$ have dramatically clarified the nature of the pyrolysis in the micro-reactors. These devices operate in a steady-state $(\mathrm{CW})$ mode when using synchrotron photons (LBNL Advanced Light Source and Paul Scherrer Institute Swiss Light Source) or in a pulsed mode for 10.487 eV PIMS and IR studies. During a CW experiment, the volumetric flow rate is controlled using a mass flow controller, and the pressure is measured just upstream of the reactor and in the downstream vacuum chambers. The upstream pressure typically ranges from 10 Torr to 400 Torr depending on the heating temperature and flow rate. In the $\mathrm{CW}$ case, an interesting result of these simulations was the discovery of a "sweet-spot," which emerges from the interaction of the rising gas temperature and the rapidly falling gas pressure, as will be discussed later in the paper. For a pulsed reactor, the flow rate is determined by the time-dependent geometry of the valve pintle and orifice, which unfortunately is not well known.

TABLE II. Summary of experimental conditions.

\begin{tabular}{|c|c|c|c|c|c|c|}
\hline & Carrier gas & Flow & Ionization source & $\begin{array}{l}\text { Backing pressure } \\
\text { (Torr) }\end{array}$ & $\begin{array}{l}\text { Outlet pressure } \\
\text { (Torr) }\end{array}$ & Reactor geometry \\
\hline $\begin{array}{l}\text { Photoionization mass } \\
\text { spectrometry in Colorado }\end{array}$ & Helium & Pulsed & $\begin{array}{c}118.2 \mathrm{~nm}(10.487 \mathrm{eV}) \\
\text { laser }\end{array}$ & 1500 & $2 \times 10^{-6}$ & $\begin{array}{l}\text { I.D. } 1 \mathrm{~mm} \\
\text { heated length: } 15 \mathrm{~mm}\end{array}$ \\
\hline $\begin{array}{l}\text { Photoionization mass } \\
\text { spectrometry at the ALS }\end{array}$ & Helium & Continuous & Tunable synchrotron & 50 & $2 \times 10^{-5}$ & $\begin{array}{c}\text { I.D. } 0.6 \mathrm{~mm} \\
\text { heated length: } 10 \mathrm{~mm}\end{array}$ \\
\hline $\begin{array}{l}\text { Photoionization mass } \\
\text { spectrometry at the SLS }\end{array}$ & Argon & Continuous & Tunable synchrotron & 50 & $5 \times 10^{-6}$ & $\begin{array}{l}\text { I.D. } 1 \mathrm{~mm} \\
\text { heated length: } 15 \mathrm{~mm}\end{array}$ \\
\hline $\begin{array}{l}\text { Matrix isolation IR spectroscopy } \\
\text { in Colorado }\end{array}$ & Neon & Pulsed & None & 1000 & $2 \times 10^{-6}$ & $\begin{array}{l}\text { I.D. } 1 \mathrm{~mm} \\
\text { heated length: } 10 \mathrm{~mm}\end{array}$ \\
\hline
\end{tabular}


The characteristics of $\mathrm{CW}$ and pulsed flows are quite different. In a steady-state laminar flow, the time-dependent terms in the Navier-Stokes equation drop out of the equation. In our situation, the geometry is fixed and the mass flow rate is controlled, thus making CFD numerical solutions tractable ${ }^{42}$ and detailed flow field information attainable. Given a reaction mechanism and kinetic parameters, one can include chemistry in the simulations, predicting, for example, the overall conversion percentage of the reactant. As a result, simulations can be used to test reaction mechanisms. In a pulsed flow, the geometry is varying in time due to motion of the pintle within the valve and the instantaneous mass flow rate is thus unknown. Furthermore, the duty cycle is such that the tubular reactor gets completely purged of gas between pulses resulting in a highly complex transient flow that transitions from collisionless to collision-dominated over the course of a few milliseconds. This is a formidable problem to model and is the subject of current research.

\section{RESULTS}

We have chosen benzyl bromide and ethylbenzene as convenient precursors of the benzyl radical,

$$
\begin{aligned}
\mathrm{C}_{6} \mathrm{H}_{5} \mathrm{CH}_{2} \mathrm{Br}(+\mathrm{M}) & \rightarrow \mathrm{C}_{6} \mathrm{H}_{5} \mathrm{CH}_{2}+\mathrm{Br}, \\
\mathrm{C}_{6} \mathrm{H}_{5} \mathrm{CH}_{2} \mathrm{CH}_{3}(+\mathrm{M}) & \rightarrow \mathrm{C}_{6} \mathrm{H}_{5} \mathrm{CH}_{2}+\mathrm{CH}_{3} .
\end{aligned}
$$

Table I shows that $\Delta_{\mathrm{rxn}} H_{298}$ (1) is $61 \pm 1 \mathrm{kcal} \mathrm{mol}^{-1}(260 \pm 4$ $\mathrm{kJ} \mathrm{mol}^{-1}$ ) while $\Delta_{\mathrm{rxn}} H_{298}$ (2) is $77.6 \pm 0.7 \mathrm{kcal} \mathrm{mol}^{-1}(325$ $\pm 3 \mathrm{~kJ} \mathrm{~mol}^{-1}$ ). Because of the differing thermochemistry between reactions (1) and (2), benzyl radicals are observed at lower decomposition temperatures when using $\mathrm{C}_{6} \mathrm{H}_{5} \mathrm{CH}_{2} \mathrm{Br}$ than with $\mathrm{C}_{6} \mathrm{H}_{5} \mathrm{CH}_{2} \mathrm{CH}_{3}$. However, the higher vapor pressure of ethylbenzene makes sample preparation comparatively simpler. An important experimental difficulty associated with benzyl bromide is dissociative ionization. The $I E$ of $\mathrm{C}_{6} \mathrm{H}_{5} \mathrm{CH}_{2} \mathrm{Br}$ is $9.0 \mathrm{eV}$ (see Table I) and so $10.5 \mathrm{eV}(118.2 \mathrm{~nm}$ ) PIMS is $1.5 \mathrm{eV}$ above the ionization threshold. Consequently, the ion resulting from irradiating $\mathrm{C}_{6} \mathrm{H}_{5} \mathrm{CH}_{2} \mathrm{Br}$ with 118.2 $\mathrm{nm},\left[\mathrm{C}_{6} \mathrm{H}_{5} \mathrm{CH}_{2} \mathrm{Br}^{+}\right]^{*}(\mathrm{~m} / \mathrm{z} 170 / 172)$, commonly fragments to $\mathrm{C}_{6} \mathrm{H}_{5} \mathrm{CH}_{2}{ }^{+}(\mathrm{m} / \mathrm{z}$ 91) and Br. This dissociative ionization process obscures the $\mathrm{m} / \mathrm{z} 91$ signal that results from thermally formed benzyl radicals. While the $I E\left(\mathrm{C}_{6} \mathrm{H}_{5} \mathrm{CH}_{2} \mathrm{CH}_{3}\right)$ is $8.8 \mathrm{eV}$ (see Table I), very few of the $\mathrm{C}_{6} \mathrm{H}_{5} \mathrm{CH}_{2} \mathrm{C}_{3}{ }^{+}(\mathrm{m} / \mathrm{z}$ 106) cations subsequently fragment, making for cleaner PIMS spectra. Synchrotron radiation is especially useful for taking PIMS spectra of benzyl bromide because the ionization source can be lowered to just above the ionization energy of the precursor, $9 \mathrm{eV}$.

\section{A. Decomposition of benzyl- $d_{0}$ radical}

Fig. 2 shows the $118.2 \mathrm{~nm}$ PIMS spectrum that results from pyrolysis of a dilute sample of $\mathrm{C}_{6} \mathrm{H}_{5} \mathrm{CH}_{2} \mathrm{CH}_{3}(0.02 \%$ in $\mathrm{He}$ ). The bottom scan was recorded with the reactor at $350 \mathrm{~K}$ and the spectra only show ions resulting from the parent at $\mathrm{m} / \mathrm{z}$ 106 and a proper isotope peak at $\mathrm{m} / \mathrm{z} 107$. There is a small feature at $\mathrm{m} / \mathrm{z} 91$ resulting from dissociative ionization of the $\mathrm{C}_{6} \mathrm{H}_{5} \mathrm{CH}_{2} \mathrm{CH}_{3}{ }^{+}$cation $\left(\mathrm{C}_{6} \mathrm{H}_{5} \mathrm{CH}_{2} \mathrm{CH}_{3}{ }^{+} \rightarrow \mathrm{C}_{6} \mathrm{H}_{5} \mathrm{CH}_{2}{ }^{+}+\mathrm{CH}_{3}\right)$.

Pyrolysis of ethylbenzene is more likely to occur by reaction (2) but formation of the methylbenzyl radical, $\mathrm{C}_{6} \mathrm{H}_{5} \mathrm{CH}-$ $\mathrm{CH}_{3}$, is also a possibility. In a hot micro-reactor, the methylbenzyl radical will rapidly decompose to styrene and $\mathrm{H}$ atoms,

$$
\mathrm{C}_{6} \mathrm{H}_{5} \mathrm{CHCH}_{3} \rightarrow \mathrm{H}+\mathrm{C}_{6} \mathrm{H}_{5} \mathrm{CH}=\mathrm{CH}_{2} .
$$

In Fig. 2, heating the reactor to $1300 \mathrm{~K}$ triggers the decomposition of ethylbenzene to produce the benzyl $(\mathrm{m} / \mathrm{z} 91)$ and methyl radicals $(\mathrm{m} / \mathrm{z} 15)$. There is no evidence for the presence of styrene, $\mathrm{C}_{6} \mathrm{H}_{5} \mathrm{CH}=\mathrm{CH}_{2}, \mathrm{~m} / \mathrm{z}$ 104, which indicates that there is no formation of the $\mathrm{C}_{6} \mathrm{H}_{5} \mathrm{CH}-\mathrm{CH}_{3}$ radical.

Once the benzyl- $\mathrm{d}_{0}$ radical is produced, it begins to fragment. At $1300 \mathrm{~K}$, pyrolysis of $\mathrm{C}_{6} \mathrm{H}_{5} \mathrm{CH}_{2}$ is underway and ions at $\mathrm{m} / \mathrm{z}$ 65, 51, 41, and 39 appear. Raising the microreactor temperature to $1400 \mathrm{~K}$ leads to the appearance of ions at $\mathrm{m} / \mathrm{z}$ 63, 64, 89, and 90. The pyrolysis scheme in Fig. 1 suggests that an assignment for these features to be fulvenallene $\left(\mathrm{C}_{5} \mathrm{H}_{4}=\mathrm{C}=\mathrm{CH}_{2}\right), \mathrm{m} / \mathrm{z}$ 90, and the fulvenallenyl radical $\left(\mathrm{C}_{5} \mathrm{H}_{4}-\mathrm{C} \equiv \mathrm{CH}\right), \mathrm{m} / \mathrm{z} 89$. The $I E\left(\mathrm{C}_{5} \mathrm{H}_{4}=\mathrm{C}=\mathrm{CH}_{2}\right)$ is $8.22 \mathrm{eV}$ while $I E\left(\mathrm{C}_{5} \mathrm{H}_{4}-\mathrm{C} \equiv \mathrm{CH}\right)$ is $8.19 \mathrm{eV}$ (see Table I) so the 118.2 $\mathrm{nm}$ VUV laser can ionize both. The strong band at $\mathrm{m} / \mathrm{z} 65$ is cyclopentadienyl with an $I E\left(\mathrm{C}_{5} \mathrm{H}_{5}\right)$ of $8.4 \mathrm{eV}$ (see Table I), $\mathrm{m} / \mathrm{z} 39$ is likely propargyl radical with an $I E\left(\mathrm{HCCCH}_{2}\right)$ of 8.7 $\mathrm{eV}$, and $\mathrm{m} / \mathrm{z} 15$ is methyl radical, $I E\left(\mathrm{CH}_{3}\right)$ is $9.8 \mathrm{eV}$. The weak features at $\mathrm{m} / \mathrm{z} 41$ are very likely $\mathrm{CH}_{2} \mathrm{CHCH}_{2}{ }^{+}$and m/z 51 is probably protonated diacetylene, $\left(\mathrm{HC} \equiv \mathrm{C}-\mathrm{C} \equiv \mathrm{CH}, \mathrm{H}^{+}\right)$.

The top trace in Fig. 2 is pyrolysis of ethylbenzene at $1500 \mathrm{~K}$ and it is apparent that new chemistry is taking place.

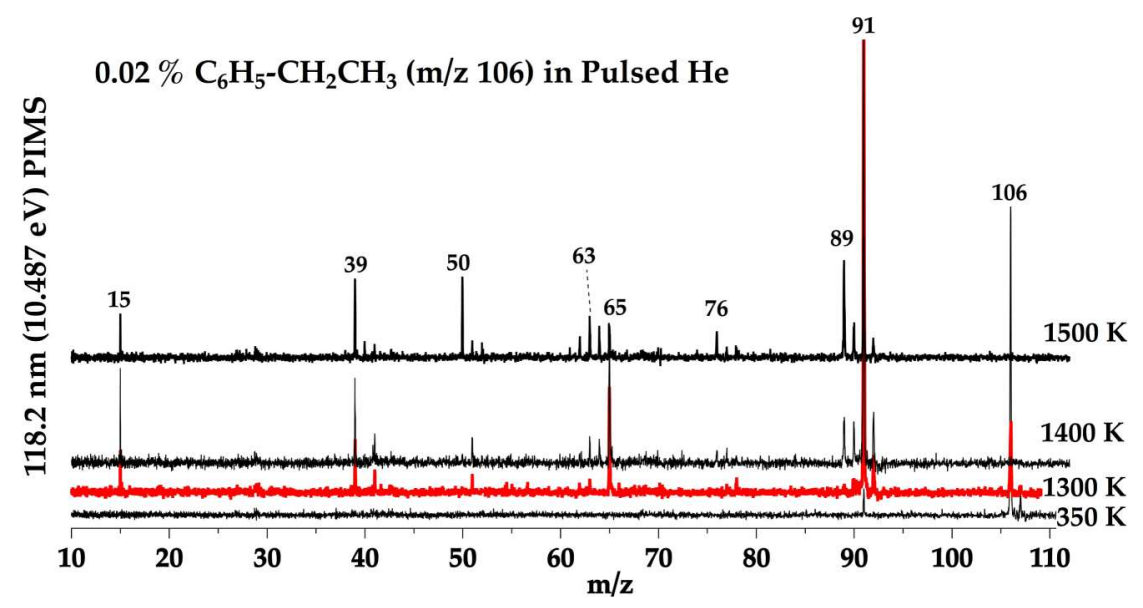

FIG. 2. Dilute ethylbenzene $\left(\mathrm{C}_{6} \mathrm{H}_{5} \mathrm{CH}_{2}\right.$ $\mathrm{CH}_{3}$ ) heated in a pulsed helium tubular micro-reactor studied using PIMS at four different reactor temperatures, 350 $\mathrm{K}, 1300 \mathrm{~K}, 1400 \mathrm{~K}$, and $1500 \mathrm{~K}$. At $1300 \mathrm{~K}$ (shown in red), the large peak at $\mathrm{m} / \mathrm{z} 91$ is benzyl radical, along with the associated fragment methyl radical (m/z 15). Some decomposition to $\mathrm{m} / \mathrm{z}$ 65 and 39 is observed. Further heating to $1400 \mathrm{~K}$ and $1500 \mathrm{~K}$ shows significant destruction of benzyl radical and a host of fragment peaks. The y-axis scaling is arbitrarily scaled to allow easier comparison between temperatures. 
$0.05 \% \mathrm{C}_{6} \mathrm{H}_{5}-\mathrm{CH}_{2} \mathrm{CH}_{3}$ in Pulsed Neon

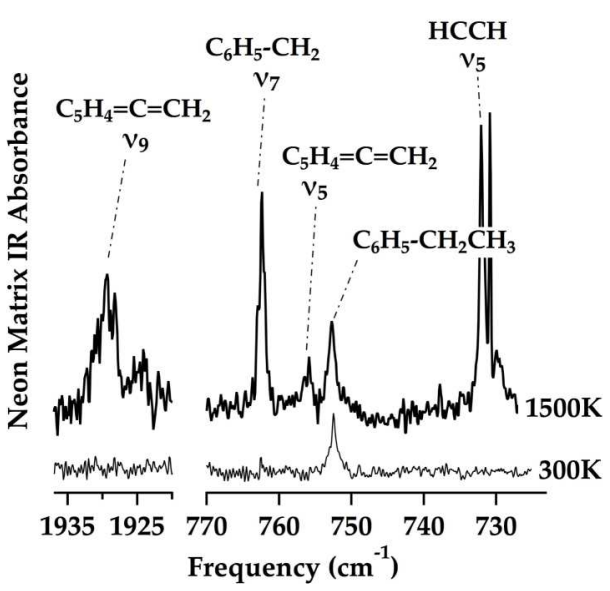

FIG. 3. Matrix isolation IR absorbance spectra of dilute ethylbenzene $\left(\mathrm{C}_{6} \mathrm{H}_{5} \mathrm{CH}_{2} \mathrm{H}_{3}\right)$ in a pulsed helium reactor at $300 \mathrm{~K}$ (thin line) and $1500 \mathrm{~K}$ (thick black line). At $300 \mathrm{~K}$, the only peak in this frequency window is from the precursor, ethylbenzene. Upon heating to $1500 \mathrm{~K}$, peaks grow in for fulvenallene, benzyl radical, and acetylene.

At $1500 \mathrm{~K}$, the benzyl radical $(\mathrm{m} / \mathrm{z}$ 91) is largely consumed and new features at $\mathrm{m} / \mathrm{z} 40,50,52,62,63,64,76$, and 77 grow in. Possible assignments for some of the other new species are $\mathrm{CH}_{3} \mathrm{C} \equiv \mathrm{CH}(\mathrm{m} / \mathrm{z} 40), \mathrm{HC} \equiv \mathrm{C}-\mathrm{C} \equiv \mathrm{CH}(\mathrm{m} / \mathrm{z} 50)$, $\mathrm{HC} \equiv \mathrm{C}-\mathrm{CH}=\mathrm{CH}_{2}(\mathrm{~m} / \mathrm{z} 52), o$-benzyne $\left(o-\mathrm{C}_{6} \mathrm{H}_{4}, \mathrm{~m} / \mathrm{z} 76\right)$, and phenyl $\left(\mathrm{C}_{6} \mathrm{H}_{5}, \mathrm{~m} / \mathrm{z} 77\right)$. The vexing problem is to apportion the source of these products. They could be new, higher temperature decomposition products of $\mathrm{C}_{6} \mathrm{H}_{5} \mathrm{CH}_{2}$ or they could be fragmentation products from the pyrolysis of fulvenallene $\left(\mathrm{C}_{5} \mathrm{H}_{4}=\mathrm{C}=\mathrm{CH}_{2}\right)$, fulvenallenyl radical $\left(\mathrm{C}_{5} \mathrm{H}_{4}-\mathrm{C} \equiv \mathrm{CH}\right)$, or cyclopentadienyl radical $\left(\mathrm{C}_{5} \mathrm{H}_{5}\right)$.

To confirm many of these assignments, we turn to IR spectroscopy and PIE measurements. Fig. 3 is a matrix IR spectrum of the results of pyrolysis of a $0.05 \%$ mixture of

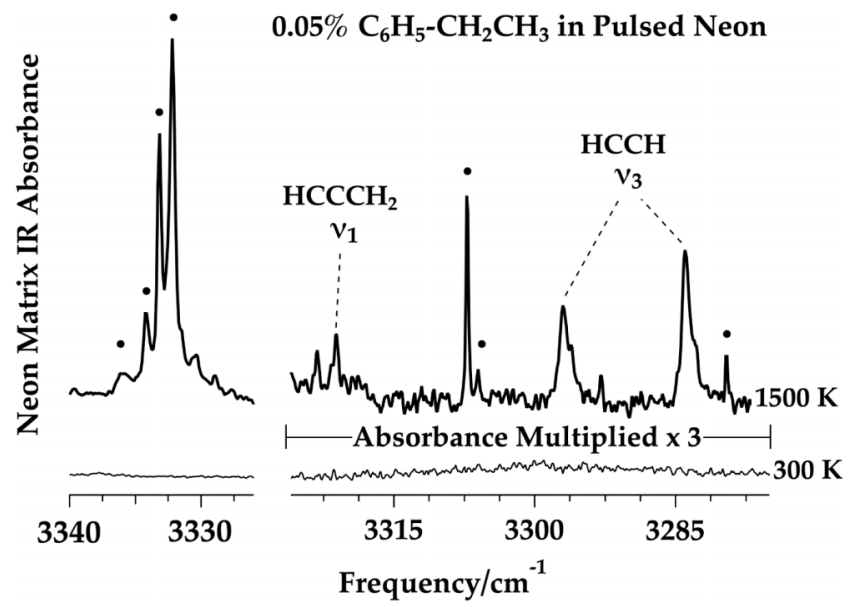

FIG. 4. The acetylenic stretch region of the vibrational spectrum is shown for the decomposition of ethylbenzene $\left(\mathrm{C}_{6} \mathrm{H}_{5} \mathrm{CH}_{2} \mathrm{H}_{3}\right)$ in pulsed neon at 300 $\mathrm{K}$ (thin line) and $1500 \mathrm{~K}$ (thick black line). Peaks for propargyl radical $\left(v_{1}\right)$ and acetylene $\left(v_{3}\right)$ are shown, here we see the Darling-Denison splitting of $v_{3}$ $(\mathrm{HCCH})$. Multiple peaks in this region remain unassigned. Molecular assignments are collected in the Supplementary IR table. ${ }^{36}$ Many candidates exist but the vibrational spectra for these molecules have not been measured. In the portion, the absorbance is multiplied by three to highlight the assigned peaks.
$\mathrm{C}_{6} \mathrm{H}_{5} \mathrm{CH}_{2} \mathrm{CH}_{3}$ in a pulsed Ne micro-reactor. The spectrum at the bottom is a control scan at $300 \mathrm{~K}$. Heating $\mathrm{C}_{6} \mathrm{H}_{5} \mathrm{CH}_{2} \mathrm{CH}_{3}$ to $1500 \mathrm{~K}$ produces the spectrum shown above. In previous work, the infrared spectra of fulvenallene were reported ${ }^{43}$ and 22 fundamentals and two overtone bands were assigned. The five strongest vibrational bands of fulvenallene have all been identified in our $\mathrm{Ne}$ matrix isolation spectrum taken during benzyl radical decomposition. These bands include $v_{4}, v_{11}, v_{22}$, $v_{28}$, and $v_{9}$, the last of which is diagnostic of a $>\mathrm{C}=\mathrm{C}=\mathrm{C}<$ allenic stretch. The IR spectrum in Fig. 3 demonstrates the presence of $v_{9}\left(\mathrm{C}_{5} \mathrm{H}_{4}=\mathrm{C}=\mathrm{CH}_{2}\right)$ and $v_{5}\left(\mathrm{C}_{5} \mathrm{H}_{4}=\mathrm{C}=\mathrm{CH}_{2}\right)$ as well as $v_{7}\left(\mathrm{C}_{6} \mathrm{H}_{5} \mathrm{CH}_{2}\right)$. The intense $v_{5}(\mathrm{HC} \equiv \mathrm{CH})$ bend is also present and is consistent with the scheme in Fig. 1. The $\mathrm{CH}$ stretching region of the IR spectrum is shown in Fig. 4. The presence of acetylene is again confirmed by observation of $v_{3}$ $(\mathrm{HC} \equiv \mathrm{CH})$ and its Darling-Dennison Resonance. The intense $v_{1}\left(\mathrm{HCCCH}_{2}\right)$ band of propargyl radical ${ }^{44}$ is detected as well. Fig. 4 also has a number of strong $\mathrm{CH}$ bands around the acetylenic stretching region, $3330-3340 \mathrm{~cm}^{-1}$, which are marked by bullets $(\bullet)$. These IR transitions have not yet been assigned since the candidate $-\mathrm{C} \equiv \mathrm{CH}$ molecules have not been assigned yet. In addition to IR identification of $\mathrm{C}_{5} \mathrm{H}_{4}=\mathrm{C}=\mathrm{CH}_{2}$, $\mathrm{C}_{6} \mathrm{H}_{5} \mathrm{CH}_{2}, \mathrm{HCCCH}_{2}$, and $\mathrm{HC} \equiv \mathrm{CH}$, we have cautious IR evidence for the $\mathrm{C}_{5} \mathrm{H}_{5}$ radical. One complication is that the two vibrations of $\mathrm{C}_{5} \mathrm{H}_{5}$ with the strongest IR intensities have been assigned ${ }^{45,46}$ to within $5 \mathrm{~cm}^{-1}$ of intense bands of benzyl radical, ${ }^{45}$ making exact identification impossible at our spectral resolution. However, other fundamentals of the $\mathrm{C}_{5} \mathrm{H}_{5}$ radical, $v_{2}, v_{3}, v_{6}$, and $v_{14}$, have been observed following the pyrolysis of $\mathrm{C}_{6} \mathrm{H}_{5} \mathrm{CH}_{2} \mathrm{CH}_{3}$. Many of the vibrational modes that are assigned in this study are collected together in the supplementary material. ${ }^{36}$

In addition to IR spectroscopy, the measurement of PIE curves can be used to identify products. Fig. 5 shows the PIE $(\mathrm{m} / \mathrm{z} 76)$ and PIE $(\mathrm{m} / \mathrm{z} 65)$ that result when a $0.2 \%$ mixture of $\mathrm{C}_{6} \mathrm{H}_{5} \mathrm{CH}_{2} \mathrm{CH}_{3}$ in a $\mathrm{CW}$ He reactor is thermally decomposed at $1500 \mathrm{~K}$. The PIE curve for $\mathrm{m} / \mathrm{z} 76$ has an ionization threshold

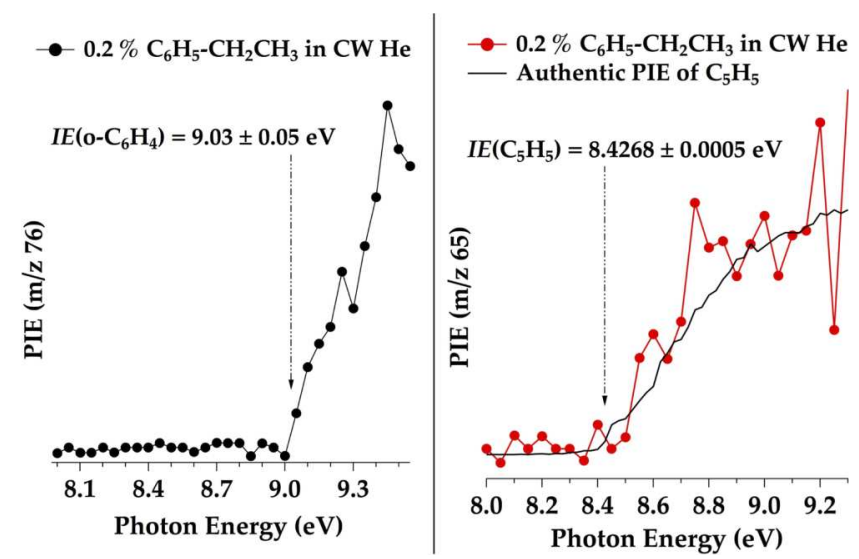

FIG. 5. Photoionization efficiency (PIE) curves for $\mathrm{m} / \mathrm{z} 76$ (left) and $\mathrm{m} / \mathrm{z} 65$ (right) measured during the $1500 \mathrm{~K}$ decomposition of $0.2 \%$ ethylbenzene $\left(\mathrm{C}_{6} \mathrm{H}_{5} \mathrm{CH}_{2} \mathrm{H}_{3}\right)$ in a $\mathrm{CW}$ helium reactor. The ionization energy ${ }^{47}$ of orthobenzyne $\left(\mathrm{C}_{6} \mathrm{H}_{4}\right)$ is included and the signal at $\mathrm{m} / \mathrm{z} 76$ shows good agreement with this value. Published values for $I E$ values of benzyne and cyclopentadienyl radical are collected in Table I. To confirm m/z 65 is cyclopentadienyl radical, the authentic ${ }^{49} \mathrm{PIE}$ of $\mathrm{C}_{5} \mathrm{H}_{5}$ is overlaid with the experimental trace, which confirms the identity as the cyclopentadienyl radical. 


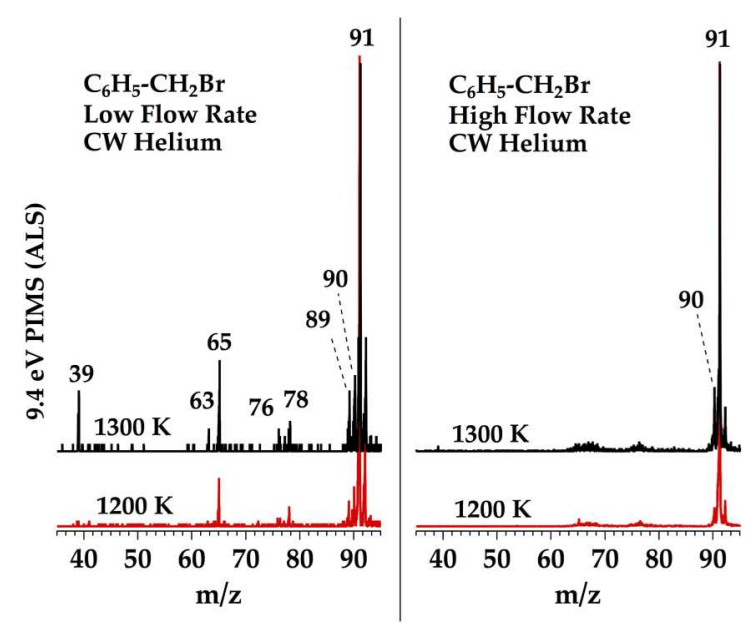

FIG. 6. PIMS spectra recorded during the decomposition of benzyl bromide at $1200 \mathrm{~K}$ (red) and $1300 \mathrm{~K}$ (black) in a CW reactor. Helium gas was flowed over the liquid sample of benzyl bromide at two different mass flow rate settings, $5 \mathrm{sccm}$ and $100 \mathrm{sccm}$. Aside from the different flow rates, the scans are otherwise identical and peaks at $\mathrm{m} / \mathrm{z} 65$ and 39 clearly depend dramatically on the flow rate setting. All spectra shown are normalized so that the peak at $\mathrm{m} / \mathrm{z} 91$ extends the height of the plot.

that is consistent with that ${ }^{47}$ of $o-$ benzyne, $9.03 \pm 0.5 \mathrm{eV}$. Likewise, the PIE $(\mathrm{m} / \mathrm{z} 65)$ is consistent with the measured ${ }^{48}$ $I E\left(\mathrm{C}_{5} \mathrm{H}_{5}\right)$ of $8.4268 \pm 0.0005 \mathrm{eV}$; the PIE (m/z 65) in Fig. 5 shows good agreement with the measured ${ }^{49} \mathrm{PIE}$ curve for the cyclopentadienyl radical, $\mathrm{C}_{5} \mathrm{H}_{5}$.

Figs. 6 and 7 introduce an important experimental complication. As mentioned in the Introduction, these heated microreactors are complex, nonlinear devices predicted ${ }^{42}$ to have a reaction "sweet-spot." This results from the interaction of the rapidly rising gas temperature and the falling gas pressure. Consequently, kinetic properties of the reactor will be very sensitive with changes in gas pressure, flow rates, nature of the buffer gas, dimensions of the reactor, and potentially other factors that have not been considered yet.

In Figs. 6 and 7, benzyl bromide has been used as a source of the $\mathrm{C}_{6} \mathrm{H}_{5} \mathrm{CH}_{2}$ radical because the thermochemistry [in reaction (1) and Table I] implies ease of decomposition of $\mathrm{C}_{6} \mathrm{H}_{5} \mathrm{CH}_{2} \mathrm{Br}$; consequently benzyl bromide provides a lower temperature source of benzyl radical. In Fig. 6, a $\mathrm{CW} \mathrm{SiC}$ micro-reactor is used with a high flow rate of $\mathrm{He}$ (right panel) as well as a low flow rate (left panel). It is apparent that reactors with different flow rates decompose the $\mathrm{C}_{6} \mathrm{H}_{5} \mathrm{CH}_{2} \mathrm{Br}$ sample to different extents. The synchrotron at the ALS is operating at $9.4 \mathrm{eV}$ so the signals in the PIMS should not arise from dissociative ionization. The low flow rate scan $(5 \mathrm{sccm})$ in Fig. 6 is consistent with the $1300 \mathrm{~K}$ scan in Fig. 2, which uses $\mathrm{C}_{6} \mathrm{H}_{5} \mathrm{CH}_{2} \mathrm{CH}_{3}$ as a benzyl source in a pulsed He reactor with $118.2 \mathrm{~nm}$ PIMS. Signals corresponding to fulvenallene $(\mathrm{m} / \mathrm{z}$ 90), fulveneallenyl (m/z 89), cyclopentadienyl (m/z 65), and propargyl (m/z 39) are evident. However, the right panel in Fig. 6 shows that when the micro-reactor is operated at higher flow (100 sccm) conditions, $\mathrm{C}_{5} \mathrm{H}_{4}=\mathrm{C}=\mathrm{CH}_{2}(\mathrm{~m} / \mathrm{z} 90)$ is present but only weak signals at $\mathrm{m} / \mathrm{z} 65$ or $\mathrm{m} / \mathrm{z} 39$ are detected. The two scans in Fig. 6 were measured under the same experimental conditions except for the flow rate. It appears that different chemistry occurs in the $\mathrm{CW}$ reactor with different flow rates even though the wall temperature is the same.

Changing the buffer gas from helium to argon can also lead to variability in experimental findings. Fig. 7 shows the pyrolysis of $\mathrm{C}_{6} \mathrm{H}_{5} \mathrm{CH}_{2} \mathrm{Br}$ entrained in $\mathrm{Ar}$ in a CW SiC microreactor measured at the Swiss Light Source. The left panel in Fig. 7 demonstrates that the initial decomposition products of $\mathrm{C}_{6} \mathrm{H}_{5} \mathrm{CH}_{2}$ at $1150 \mathrm{~K}$ in a $\mathrm{CW}$ Ar source are $\mathrm{C}_{5} \mathrm{H}_{4}=\mathrm{C}=\mathrm{CH}_{2}$ $\left(\mathrm{m} / \mathrm{z}\right.$ 90) and $\mathrm{C}_{5} \mathrm{H}_{4}-\mathrm{C} \equiv \mathrm{CH}(\mathrm{m} / \mathrm{z}$ 89). The decomposition scheme in Fig. 1 indicates that $\mathrm{C}_{5} \mathrm{H}_{4}-\mathrm{C} \equiv \mathrm{CH}$ originates from $\mathrm{C}_{5} \mathrm{H}_{4}=\mathrm{C}=\mathrm{CH}_{2}$ via loss of a $\mathrm{H}$ atom. The right panel in Fig. 7 uses the SLS synchrotron at $13.8 \mathrm{eV}$ to photoionize hydrogen atom and it is apparent that there are $\mathrm{H}$ atoms present at $1150 \mathrm{~K}$. Figs. 6 and 7 imply that differences in operational conditions (temperature, pressure) or carrier gas ( $\mathrm{He}, \mathrm{Ar}$ ) are very important to the product distributions of thermal fragmentation.

Recent CFD simulations ${ }^{42}$ are currently limited to $\mathrm{CW}$ reactors but are able to provide insight into the comparison between experiments using $\mathrm{Ar}$ or $\mathrm{He}$ as a carrier gas. Given similar conditions, a reactor using He will exhibit considerably hotter temperature profiles along the reactor length, showing both higher peak temperature and more rapid heating. Furthermore, the residence time is a function of the mass flow rate. Both of these flow dependencies will alter the decomposition environment present and may explain the differences indicated by Figs. 6 and 7. Since decomposition pathways have differing temperatures dependence, varying the reactor environment may dramatically alter the decomposition products.

\section{B. Decomposition of benzyl- $d_{2}$ radical}

Fig. 8 shows the result of pyrolysis of $\mathrm{C}_{6} \mathrm{H}_{5} \mathrm{CD}_{2} \mathrm{CD}_{3}$; the predicted fragmentation of $\mathrm{C}_{6} \mathrm{H}_{5} \mathrm{CD}_{2}$ is presented in the
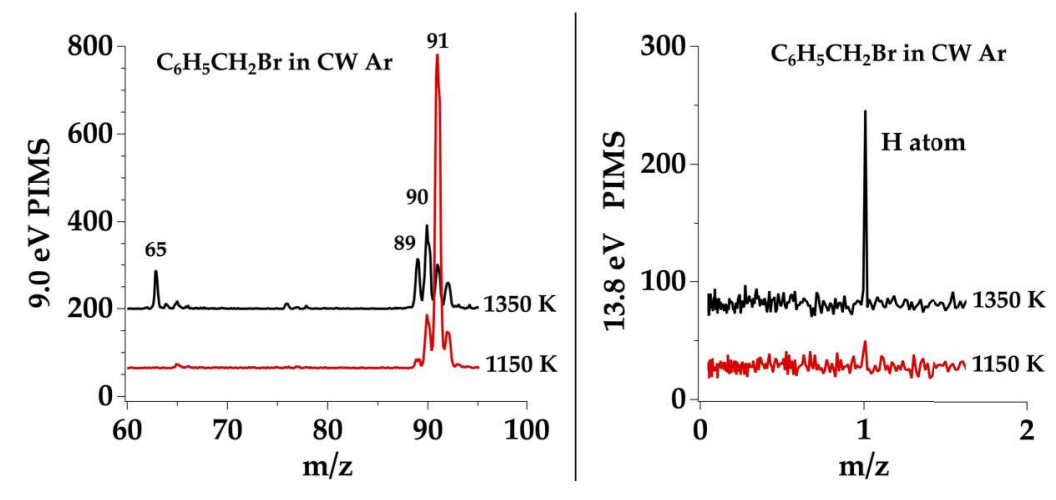

FIG. 7. Thermal decomposition of benzyl bromide in a $\mathrm{CW}$ argon reactor measured at the tunable synchrotron lights source at the SLS. The left panel shows the formation of $\mathrm{m} / \mathrm{z} 90\left(\mathrm{C}_{5} \mathrm{H}_{4}=\mathrm{C}=\mathrm{CH}_{2}\right)$ and $89\left(\mathrm{C}_{5} \mathrm{H}_{4}-\mathrm{C} \equiv \mathrm{CH}\right)$ during the $1150 \mathrm{~K}$ decomposition of benzyl radical $(\mathrm{m} / \mathrm{z}$ 91). The photon energy was set to $9.0 \mathrm{eV}$, just high enough to ionize these products. The right panel shows the appearance of product hydrogen atom $(\mathrm{m} / \mathrm{z} 1)$ at the same temperature $\left(\mathrm{C}_{6} \mathrm{H}_{5} \mathrm{CH}_{2} \rightarrow \mathrm{C}_{5} \mathrm{H}_{4}=\mathrm{C}=\mathrm{CH}_{2}+\mathrm{H}\right)$. To ionize hydrogen atom, $13.8 \mathrm{eV}$ photons were used. 
$0.02 \% \mathrm{C}_{6} \mathrm{H}_{5}-\mathrm{CD}_{2} \mathrm{CD}_{3}(\mathrm{~m} / \mathrm{z}$ 111) in Pulsed He

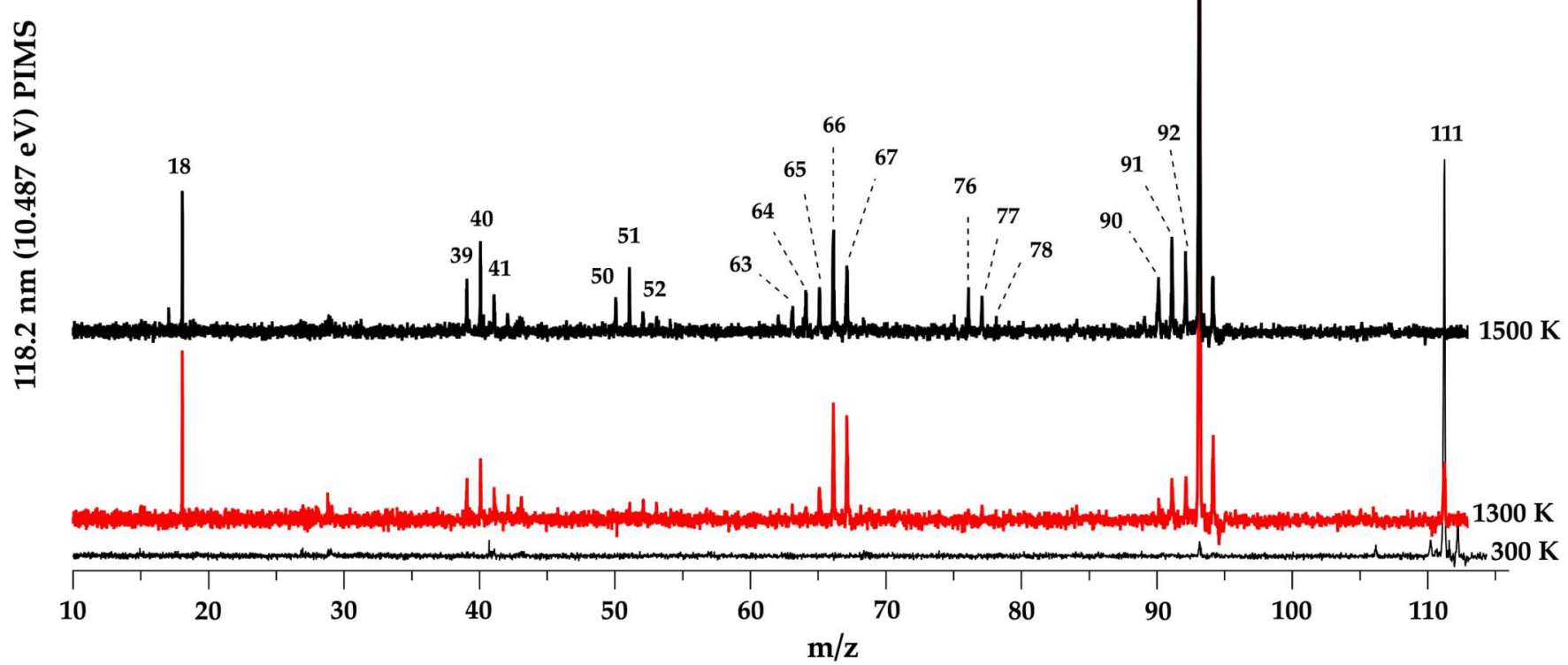

FIG. 8. Dilute ethylbenzene- $\mathrm{d}_{5}\left(\mathrm{C}_{6} \mathrm{H}_{5} \mathrm{CD}_{2} \mathrm{CD}_{3}, \mathrm{~m} / \mathrm{z}\right.$ 111) heated in a pulsed helium tubular micro-reactor studied using PIMS at three different reactor temperatures, $300 \mathrm{~K}, 1300 \mathrm{~K}$, and $1500 \mathrm{~K}$. At $1300 \mathrm{~K}$ (shown in red), the large peak at m/z 93 is benzyl radical- $\mathrm{d}_{2}$, along with the counter fragment methyl radical- $\mathrm{d}_{3}(\mathrm{~m} / \mathrm{z} 18)$. Some decomposition is observed resulting in cyclopentadienyl radical (m/z 65 is $\mathrm{d}_{0}, 66$ is $\mathrm{d}_{1}$, and 67 is $\mathrm{d}_{2}$ ) and 39,40 , and 41 (presumed to be propargyl radical) are observed. At $1500 \mathrm{~K}$, we see peaks at 90, 91, and 92, 50, 51, and 52, and a triplet at 76, 77, and 78. Comparison to Fig. 2 (the $\mathrm{d}_{0}$ case) is useful. The y-axis scaling is arbitrarily scaled to allow easy comparison between temperatures.

supplementary figure, ${ }^{36}$ Fig. S1. The signals at $\mathrm{m} / \mathrm{z} 111$ and $\mathrm{m} / \mathrm{z} 112$ are present from photoionization of $\mathrm{C}_{6} \mathrm{H}_{5} \mathrm{CD}_{2} \mathrm{CD}_{3}$ and its natural abundance isotope peak. Small peaks at $\mathrm{m} / \mathrm{z} 93$ (dissociative ionization) and an impurity peak at $\mathrm{m} / \mathrm{z} 110$ are also present. At $1300 \mathrm{~K}$, the decomposition of $\mathrm{C}_{6} \mathrm{H}_{5} \mathrm{CD}_{2} \mathrm{CD}_{3}$ is demonstrated by the presence of $\mathrm{CD}_{3}(\mathrm{~m} / \mathrm{z} 18)$ and $\mathrm{C}_{6} \mathrm{H}_{5} \mathrm{CD}_{2}$ $(\mathrm{m} / \mathrm{z}$ 93). Complications with the scheme in Fig. 1 are immediately evident. This scheme would predict $\mathrm{C}_{6} \mathrm{H}_{5} \mathrm{CD}_{2}$ to lose $\mathrm{H}$ atom and produce fulvenallene- $\mathrm{d}_{2}(\mathrm{~m} / \mathrm{z}$ 92) followed by loss of $\mathrm{D}$ atom to generate fulvenallenyl radical (m/z 90). Fig. 1 would also predict formation of cyclopentadienyl radical- $\mathrm{d}_{0}(\mathrm{~m} / \mathrm{z} 65)$ and acetylene- $\mathrm{d}_{2}$ (DCCD, m/z 28). Fig. 8 clearly shows the presence of the un-expected peak $\mathrm{m} / \mathrm{z} 91$ as well as formation of intense signals at $\mathrm{m} / \mathrm{z} 66$ and 67 in addition to the expected peak at $\mathrm{m} / \mathrm{z}$ 65. Also present are ions at $\mathrm{m} / \mathrm{z}(39,40,41,42$, and 43 ). As the micro-reactor is heated to $1500 \mathrm{~K}$, numerous un-expected species appear. Among these new peaks at 1500 $\mathrm{K}$ are that of $\mathrm{m} / \mathrm{z} 17, \mathrm{CHD}_{2}$.

A potential factor for many of these new peaks is the fact that radical-radical processes in these micro-reactors have been observed earlier. In a study of the pyrolysis of isotopically substituted acetaldehydes ${ }^{50}$ rapid isotope exchanges were observed: $\mathrm{CD}_{3}(\mathrm{~m} / \mathrm{z} 18)+\mathrm{H} \leftrightharpoons \mathrm{CHD}_{2}(\mathrm{~m} / \mathrm{z} 17)+\mathrm{D}$. Likewise in an earlier study of the pyrolysis of furan, ${ }^{51}$ it was observed that $\mathrm{H}$ atoms attacked $\mathrm{CH}_{3} \mathrm{C} \equiv \mathrm{CH}$ to produce $\mathrm{CH}_{3}$ radicals $(\mathrm{m} / \mathrm{z} 15)$ and $\mathrm{HCCH}$. Careful dilution of the furan sample to $0.01 \%$ (or lower) in He was required ${ }^{51}$ to suppress this $\mathrm{H}$ atom chemistry. The reaction scheme in Fig. 1 predicts the formation of $\mathrm{H}$ atoms and confirmation of this is found in Fig. 7, which shows PIMS detection of $\mathrm{H}$ atoms following pyrolysis of $\mathrm{C}_{6} \mathrm{H}_{5} \mathrm{CH}_{2}$.

One explanation of the unexpected sets of peaks in Fig. 8 could be rapid radical/radical, bimolecular chemistry. Many radical/radical reactions are very fast, ${ }^{52}$

$$
\mathrm{C}_{5} \mathrm{H}_{5}(\mathrm{~m} / \mathrm{z} 65)+\mathrm{D} \leftrightharpoons\left[\mathrm{C}_{5} \mathrm{H}_{5} \mathrm{D}\right]^{*} \leftrightharpoons \mathrm{C}_{5} \mathrm{H}_{4} \mathrm{D}(\mathrm{m} / \mathrm{z} 66)+\mathrm{H} .
$$

To find more direct evidence for H/D atom chemistry, we have examined the chemistry of $\mathrm{D}$ atoms reacting with cyclopentadienyl radicals. In an earlier study ${ }^{25}$ of the pyrolysis of benzaldehyde, methyl nitrite- $\mathrm{d}_{3}$ was used as a chemical source of $\mathrm{D}$ atoms,

$$
\mathrm{CD}_{3} \mathrm{ONO}(+\mathrm{M}) \rightarrow \mathrm{D}+\mathrm{CD}_{2} \mathrm{O}+\mathrm{NO} .
$$

Additionally, anisole $\left(\mathrm{C}_{6} \mathrm{H}_{5} \mathrm{OCH}_{3}\right)$ is known ${ }^{29}$ to be a convenient source of $\mathrm{C}_{5} \mathrm{H}_{5}$ radicals so we can test for rapid D atom reactions with cyclopentadienyl radical. Fig. 9 shows the results of this examination. The thin trace is from thermal decomposition of anisole at $1300 \mathrm{~K}$,

$$
\begin{aligned}
\mathrm{C}_{6} \mathrm{H}_{5} \mathrm{OCH}_{3}(+\mathrm{M}) & \rightarrow\left[\mathrm{C}_{6} \mathrm{H}_{5} \mathrm{O}\right]+\mathrm{CH}_{3} \\
& \rightarrow \mathrm{C}_{5} \mathrm{H}_{5}(\mathrm{~m} / \mathrm{z} 65)+\mathrm{CO}+\mathrm{CH}_{3}(\mathrm{~m} / \mathrm{z} 15) .
\end{aligned}
$$

The thicker trace in Fig. 9 is the result of pyrolysis of a mixture of $0.02 \% \mathrm{C}_{6} \mathrm{H}_{5} \mathrm{OCH}_{3}$ and $0.25 \% \mathrm{CD}_{3} \mathrm{ONO}$ in a pulsed $\mathrm{He}$ reactor at $1300 \mathrm{~K}$. Since pyrolysis of $\mathrm{CD}_{3} \mathrm{ONO}$ produces $\mathrm{CD}_{2} \mathrm{O}(\mathrm{m} / \mathrm{z} 32)$ plus $\mathrm{NO}(\mathrm{m} / \mathrm{z} 30)$ and $\mathrm{D}$ atoms, radical-radical reactions ensue that lead to scrambling of the cyclopentadienyl 
$0.02 \% \mathrm{C}_{6} \mathrm{H}_{5} \mathrm{OCH}_{3}+0.25 \% \mathrm{CD}_{3} \mathrm{ONO}$ $0.02 \% \mathrm{C}_{6} \mathrm{H}_{5} \mathrm{OCH}_{3}$

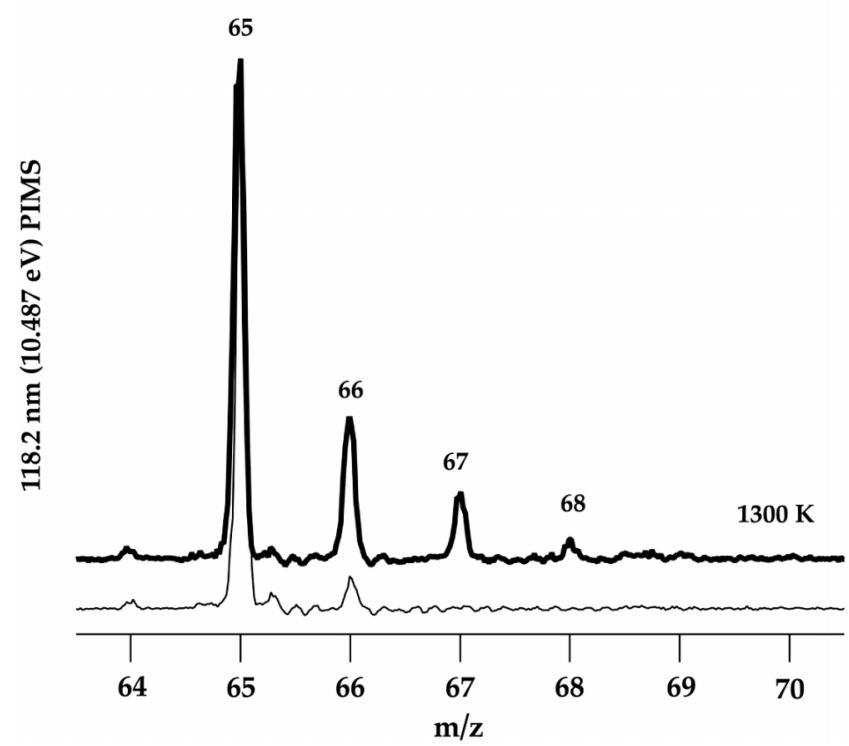

FIG. 9. The thin black trace is the PIMS spectra of $\mathrm{C}_{6} \mathrm{H}_{5} \mathrm{OCH}_{3}$ decomposition at $1300 \mathrm{~K}$ yielding cyclopentadienyl radical $\left(\mathrm{C}_{5} \mathrm{H}_{5}, \mathrm{~m} / \mathrm{z} 65\right)$ observed with a small natural abundance ${ }^{13} \mathrm{C}$ peak at $\mathrm{m} / \mathrm{z}$ 66. Shown above is the outcome of mixing $0.02 \% \mathrm{C}_{6} \mathrm{H}_{5} \mathrm{OCH}_{3}$ with $0.25 \% \mathrm{CD}_{3} \mathrm{ONO}$, a known D atom source, in pulsed helium. We can clearly see significant incorporation of $\mathrm{D}$ atom up to $\mathrm{C}_{5} \mathrm{D}_{3} \mathrm{H}_{2}$ due to bimolecular radical-radical reactions $\left(\mathrm{C}_{5} \mathrm{H}_{5}+\mathrm{D} \rightarrow \mathrm{C}_{5} \mathrm{DH}_{5} * \rightarrow \mathrm{C}_{5} \mathrm{DH}_{4}+\mathrm{H}\right)$. Note the monotonic decrease in signal observed with increasing deuteration events.

radical,

$$
\mathrm{C}_{5} \mathrm{H}_{5}{ }^{13} \mathrm{CH}_{2}(+\mathrm{M}) \leftrightharpoons\left({ }^{13} \mathrm{C}\right) \mathrm{C}_{6} \rightarrow \mathrm{HCCH}+\left({ }^{13} \mathrm{C}\right) \mathrm{C}_{4} \mathrm{H}_{5}
$$

In addition to $\mathrm{C}_{5} \mathrm{DH}_{4}$, Fig. 9 demonstrates that $\mathrm{D}$ atom chemistry can exchange multiple $\mathrm{H}$ atoms to produce both the $\mathrm{C}_{5} \mathrm{D}_{2} \mathrm{H}_{3}$ and $\mathrm{C}_{5} \mathrm{D}_{3} \mathrm{H}_{2}$ radicals as well.

This set of complimentary data helps in the interpretation of the $\mathrm{H} / \mathrm{D}$ ratios in peaks in Fig. 8. In the $1300 \mathrm{~K}$ trace for $\mathrm{C}_{6} \mathrm{H}_{5} \mathrm{CD}_{2} \mathrm{CD}_{3}$, instead of one peak at $\mathrm{m} / \mathrm{z} 65$ (assigned as $\mathrm{C}_{5} \mathrm{H}_{5}$ in Fig 2) features at 65, 66, and 67 are observed; in Fig. 8 the peaks at 66 and 67 are surprisingly intense. Decomposition of $\mathrm{C}_{6} \mathrm{H}_{5} \mathrm{CD}_{2}$ via Fig. 1 predicts formation of $\mathrm{C}_{5} \mathrm{H}_{5}$ only. It may seem initially attractive to assign m/z 66 and 67 in Fig. 8 to H/D scrambling but the intensities are inconsistent with this process. Bimolecular scrambling produces monotonically decreasing intensity for subsequent deuteration of $\mathrm{C}_{5} \mathrm{H}_{5}$, as evident in Fig. 9. Due to the qualitative differences between Figs. 8 and 9, it seems likely that the intensities for $\mathrm{C}_{5} \mathrm{H}_{4} \mathrm{D}$ (m/z 66) and $\mathrm{C}_{5} \mathrm{H}_{3} \mathrm{D}_{2}(\mathrm{~m} / \mathrm{z} 67)$ result from different pathways than those shown in Fig. 1 and not simple bimolecular H/D scrambling.

Additional indication that our experiments follow unimolecular decomposition is found in the absence of styrene formation. If hydrogen atoms were present in large enough densities to facilitate bimolecular chemistry, a likely target would be $\mathrm{H}$-atom abstraction from ethylbenzene of the $\alpha$-carbon, yielding methylbenzyl radical $\left(\mathrm{C}_{6} \mathrm{H}_{5} \mathrm{CH}-\mathrm{CH}_{3}\right)$, which would rapidly undergo hydrogen atom loss to produce styrene, see reaction (3). This process was observed during the decomposition of ethylbenzene in shock tubes and was commonly observed when bimolecular reactions dominate..$^{53}$ Since no $\mathrm{C}_{6} \mathrm{H}_{5}-\mathrm{CH}=\mathrm{CH}_{2}(\mathrm{~m} / \mathrm{z}$ 104) is observed in the PIMS spectra (Fig. 2), it is unlikely that $\mathrm{H}$ atom chemistry is prevalent under the operating conditions of the micro-reactor.

\section{Decomposition of benzyl- $d_{5}$ radical}

Fig. 10 shows the results of pyrolysis of a $0.02 \%$ mixture of $\mathrm{C}_{6} \mathrm{D}_{5} \mathrm{CH}_{2} \mathrm{CH}_{3}$ in a pulsed micro-reactor; the predicted fragmentation for $\mathrm{C}_{6} \mathrm{D}_{5} \mathrm{CH}_{2}$ is shown in the supplementary material figure, ${ }^{36} \mathrm{Fig}$. S2. The initial trace at $350 \mathrm{~K}$ shows the parent peak for $\mathrm{C}_{6} \mathrm{D}_{5} \mathrm{CH}_{2} \mathrm{CH}_{3}$ at $\mathrm{m} / \mathrm{z} 111$. The small feature at $\mathrm{m} / \mathrm{z}$ 110 reveals a slight impurity $\left(\mathrm{C}_{6} \mathrm{HD}_{4} \mathrm{CH}_{2} \mathrm{CH}_{3}\right)$ of the benzyl- $\mathrm{d}_{5}$ precursor as well as a small amount of dissociation ionization producing $\mathrm{C}_{6} \mathrm{D}_{5} \mathrm{CH}_{2}{ }^{+}$at $\mathrm{m} / \mathrm{z} 96$. At $1300 \mathrm{~K}$, a large portion of $\mathrm{C}_{6} \mathrm{D}_{5} \mathrm{CH}_{2} \mathrm{CH}_{3}$ decomposes to generate $\mathrm{C}_{6} \mathrm{D}_{5} \mathrm{CH}_{2}(\mathrm{~m} / \mathrm{z}$ 96) as well as the methyl radical, $\mathrm{m} / \mathrm{z} 15$. Instead of the expected feature for $\mathrm{C}_{5} \mathrm{D}_{5}(\mathrm{~m} / \mathrm{z} 70)$, there are additional signals at $\mathrm{m} / \mathrm{z}$ 65,68 , and 69 similar to Fig. 8. There are also a number of peaks at $\mathrm{m} / \mathrm{z}(40,41,42,44$, and 45$)$ as well as $\mathrm{m} / \mathrm{z}$ (52 and 53), which remain unassigned. As the reactor is heated to 1400 $\mathrm{K}$, benzyl- $\mathrm{d}_{5}$ radical pyrolyzes to fragments at $\mathrm{m} / \mathrm{z} 92,93,94$, and 95 . A decomposition scheme based on Fig. 1 predicts that $\mathrm{C}_{6} \mathrm{D}_{5} \mathrm{CH}_{2}\left(\mathrm{~m} / \mathrm{z}\right.$ 96) generates fulvenallene- $\mathrm{d}_{4}(\mathrm{~m} / \mathrm{z}$ 94) and the fulvenallenyl radical- $\mathrm{d}_{4}(\mathrm{~m} / \mathrm{z} 93)$; the production of radicals at $\mathrm{m} / \mathrm{z} 95$ is not anticipated. Additionally, a number of new, un-expected peaks grow in that are comparable to those found during benzyl- $\mathrm{d}_{2}$ radical decomposition.

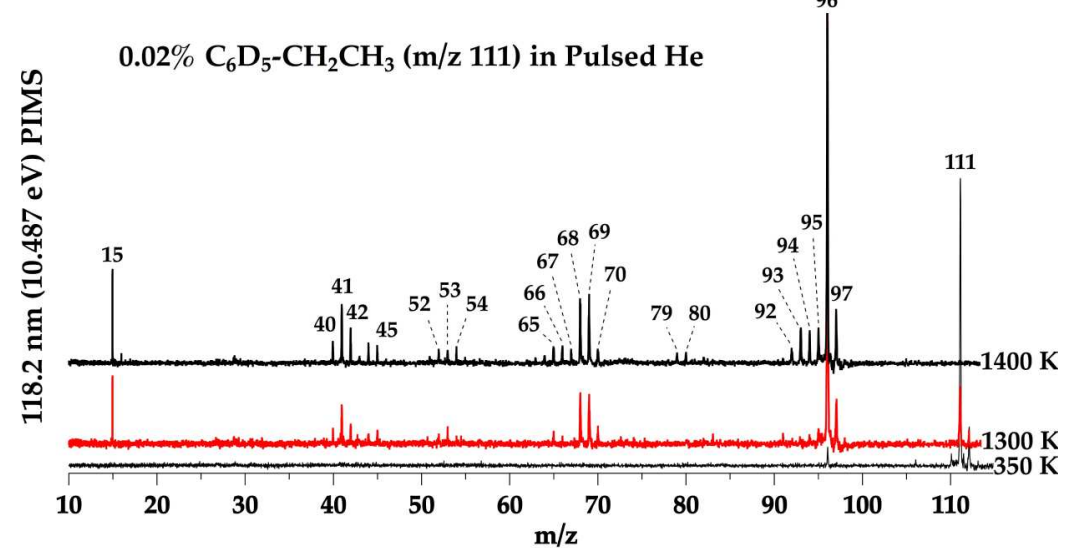

FIG. 10. Dilute ethylbenzene- $\mathrm{d}_{5}\left(\mathrm{C}_{6} \mathrm{D}_{5} \mathrm{CH}_{2} \mathrm{CH}_{3}, \mathrm{~m} / \mathrm{z}\right.$ 111 ) heated in a pulsed helium tubular micro-reactor studied using PIMS at three different reactor temperatures, $350 \mathrm{~K}, 1300 \mathrm{~K}$, and $1400 \mathrm{~K}$. The peaks here are to be compared to the $d_{0}$ case and the $d_{2}$ shown in Figs. 2 and 8, respectively. At $1300 \mathrm{~K}$ (shown in red), the large peak at $\mathrm{m} / \mathrm{z} 96$ is benzyl radical- $\mathrm{d}_{5}$, along with the counter fragment methyl radical (m/z 15). At $1300 \mathrm{~K}$, we see some decomposition to cyclopentadienyl radical $\left(\mathrm{m} / \mathrm{z} 68\right.$ is $\mathrm{d}_{3}, 69$ is $\mathrm{d}_{4}$, and 70 is $\left.\mathrm{d}_{5}\right)$ and 40,41 , and 42 are observed (likely isotopomers of propargyl radical). Further heating to $1400 \mathrm{~K}$ shows significant destruction of benzyl radical and the appearance of a set of new peaks from $\mathrm{m} / \mathrm{z} 65-70$ and $92-95$, now assumed to be isotopomers of $\mathrm{C}_{5} \mathrm{H}_{4}=\mathrm{C}=\mathrm{CH}_{2}$ and $\mathrm{C}_{5} \mathrm{H}_{4}-\mathrm{C} \equiv \mathrm{XH}$. The $\mathrm{y}$-axis scaling is arbitrarily scaled to allow easy comparison between temperatures. 


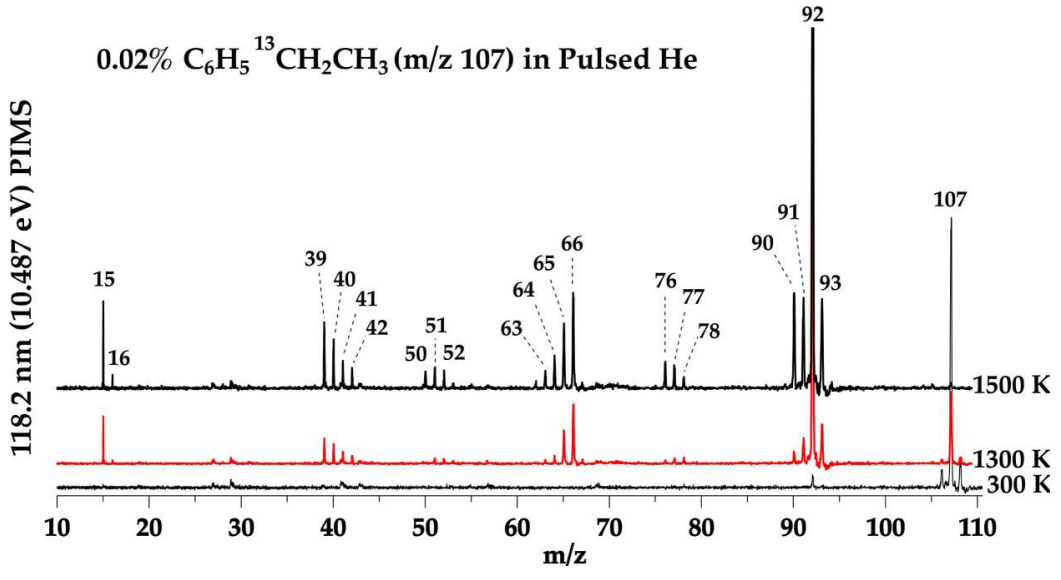

FIG. 11. Dilute ethylbenzene- ${ }^{13} \mathrm{C}\left(\mathrm{C}_{6} \mathrm{H}_{5}{ }^{13} \mathrm{CH}_{2} \mathrm{CH}_{3}, \mathrm{~m} / \mathrm{z}\right.$ 107) heated in a pulsed helium tubular micro-reactor studied using PIMS at three different reactor temperatures, $300 \mathrm{~K}, 1300 \mathrm{~K}$, and $1500 \mathrm{~K}$. At $1300 \mathrm{~K}$ (shown in red), the large peak at $\mathrm{m} / \mathrm{z} 92$ is benzyl radical- ${ }^{13} \mathrm{C}$ along with the counter fragment methyl radical $(\mathrm{m} / \mathrm{z}$ 15). Decomposition to cyclopentadienyl radical shows surprising integration of ${ }^{13} \mathrm{C}$ at $\mathrm{m} / \mathrm{z} 66$. At $1500 \mathrm{~K},{ }^{13} \mathrm{C}$ isotopomers are observed for propargyl radical $(\mathrm{m} / \mathrm{z} 40)$ and unexpectedly, methyl radical $(\mathrm{m} / \mathrm{z} 16)$ but not in the triplet at 76-78, indicating unimolecular formation of these three peaks from $\mathrm{C}_{6} \mathrm{H}_{5}{ }^{13} \mathrm{CH}_{2}$. The y-axis scaling is arbitrarily scaled to allow easy comparison between temperatures.

\section{Decomposition of ${ }^{13} \mathrm{C}$-benzyl radical, $\mathrm{C}_{6} \mathrm{H}_{5}{ }^{13} \mathrm{CH}_{2}$}

To circumvent the complications with H/D atom chemistry entirely, ${ }^{13} \mathrm{C}$ was used as an isotopic label. Shown in Fig. 11 is the $118.2 \mathrm{~nm}$ PIMS of the products of thermal fragmentation of $0.02 \% \mathrm{C}_{6} \mathrm{H}_{5}{ }^{13} \mathrm{CH}_{2} \mathrm{CH}_{3}$ in $\mathrm{He}$ in a pulsed $\mathrm{SiC}$ microreactor; the decomposition predictions for $\mathrm{C}_{6} \mathrm{H}_{5}{ }^{13} \mathrm{CH}_{2}$ are shown in the supplementary material figure, ${ }^{36} \mathrm{Fig}$. S3. The bottom scan at $300 \mathrm{~K}$ reveals the parent peak for $\mathrm{C}_{6} \mathrm{H}_{5}{ }^{13} \mathrm{CH}_{2} \mathrm{CH}_{3}$ at $\mathrm{m} / \mathrm{z}$ 107. There is a trace impurity in the ${ }^{13} \mathrm{C}$ sample, $\mathrm{C}_{6} \mathrm{H}_{5}{ }^{12} \mathrm{CH}_{2} \mathrm{CH}_{3}$ at $\mathrm{m} / \mathrm{z} 106$, and a small amount of dissociative ionization, $\mathrm{C}_{6} \mathrm{H}_{5}{ }^{13} \mathrm{CH}_{2}{ }^{+}$, at $\mathrm{m} / \mathrm{z} 92$. Heating the sample to 1300 $\mathrm{K}$ induces the formation of ${ }^{13} \mathrm{C}$-benzyl radical $\left(\mathrm{C}_{6} \mathrm{H}_{5}{ }^{13} \mathrm{CH}_{2}\right.$ at $\mathrm{m} / \mathrm{z}$ 92) along with its co-product $\mathrm{CH}_{3}(\mathrm{~m} / \mathrm{z}$ 15). Upon formation, the ${ }^{13} \mathrm{C}$-benzyl radical begins to decompose to ${ }^{13} \mathrm{C}$ fulvenallene $\left(\mathrm{m} / \mathrm{z}\right.$ 91) and the ${ }^{13} \mathrm{C}$-fulvenallenyl radical $(\mathrm{m} / \mathrm{z}$ 90). In stark contrast to expectations from Fig. 1, not only ${ }^{12} \mathrm{C}_{5} \mathrm{H}_{5}(\mathrm{~m} / \mathrm{z} 65)$ is present but also $\left({ }^{13} \mathrm{C}\right) \mathrm{C}_{4} \mathrm{H}_{5}(\mathrm{~m} / \mathrm{z} 66)$. There is also a clump of products present at $\mathrm{m} / \mathrm{z} 39,40,41$, and 42 . Further heating of $\mathrm{C}_{6} \mathrm{H}_{5}{ }^{13} \mathrm{CH}_{2} \mathrm{CH}_{3}$ to $1500 \mathrm{~K}$ leads to other peaks that are not predicted by Fig. 1. The peak at m/z 16 is certainly ${ }^{13} \mathrm{CH}_{3}$. Likewise a cluster of peaks at $\mathrm{m} / \mathrm{z}(50$, 51 , and 52) appears as well as the set at $\mathrm{m} / \mathrm{z}(76,77$, and 78). Based on measured PIE curves, we assign $\mathrm{m} / \mathrm{z} 76$ to be $o-\mathrm{C}_{6} \mathrm{H}_{4}$ and $\mathrm{m} / \mathrm{z} 78$ as benzene; $\mathrm{m} / \mathrm{z} 77$ is likely the phenyl radical, $\mathrm{C}_{6} \mathrm{H}_{5}$. Many of these features are inconsistent with the mechanisms depicted in Fig. 1. From these PIMS scans, we notice that $\mathrm{m} / \mathrm{z} 76,77$, and 78 are still present and show no sign of ${ }^{13} \mathrm{C}$ integration. This is important to note because benzene has been shown $^{29}$ to form from dimerization of propargyl radicals $\left(\mathrm{HCCCH}_{2}+\mathrm{HCCCH}_{2}\right)$, and from reactions of methyl radical with the cyclopentadienyl radical $\left(\mathrm{CH}_{3}+\mathrm{C}_{5} \mathrm{H}_{5}\right)$. If these pathways were the source of the benzene observed, then the ${ }^{13} \mathrm{C}:{ }^{12} \mathrm{C}$ ratio would match that of the two radicals reacting. Both ${ }^{13}\left(\mathrm{HCCCH}_{2}\right)$ and ${ }^{13}\left(\mathrm{C}_{5} \mathrm{H}_{5}\right)$ are present in the reactor so the absence of peaks at $\mathrm{m} / \mathrm{z} 79$ and 80 indicates that however benzene is formed, it does so without ${ }^{13} \mathrm{C}$ atoms incorporation.

To confirm the identification of the ions at $\mathrm{m} / \mathrm{z} 90$ and 91 in Fig. 11, PIEs were measured with the synchrotron at the ALS. Shown in Fig. 12 are the PIE curves for $\mathrm{m} / \mathrm{z} 90$ and $\mathrm{m} / \mathrm{z} 91$ measured during the pyrolysis of a dilute mixture of $\mathrm{C}_{6} \mathrm{H}_{5}{ }^{13} \mathrm{CH}_{2} \mathrm{CH}_{3}$ in $\mathrm{He}$ in a $\mathrm{CW} \mathrm{SiC} \mathrm{micro-reactor.} \mathrm{Both}$ of these PIE curves are consistent with the assignment of $\mathrm{m} / \mathrm{z} 90$ as the ${ }^{13} \mathrm{C}$ isotopomers of the fulvenallenyl radical $\left(\mathrm{C}_{5} \mathrm{H}_{4}-\mathrm{C} \equiv \mathrm{CH}\right)$ while $\mathrm{m} / \mathrm{z} 91$ is identified as ${ }^{13} \mathrm{C}$-fulvenallene $\left(\mathrm{C}_{5} \mathrm{H}_{4}=\mathrm{C}=\mathrm{CH}_{2}\right)$. The ionization thresholds agree with the published ${ }^{20}$ values and the known PIE curves indicated black lines. Fig. 13 shows a pair of PIE curves from the same $\mathrm{C}_{6} \mathrm{H}_{5}{ }^{13} \mathrm{CH}_{2} \mathrm{CH}_{3}$ decomposition that identify both the $\mathrm{m} / \mathrm{z} 65$ and $\mathrm{m} / \mathrm{z} 66$ signals as cyclopentadienyl radicals, ${ }^{12} \mathrm{C}_{5} \mathrm{H}_{5}$ and $\left({ }^{13} \mathrm{C} \mathrm{C}_{4} \mathrm{H}_{5}\right.$.

Fig. 1 points out that benzyl radical could isomerize to cycloheptatrienyl radical, $\mathrm{C}_{6} \mathrm{H}_{5} \mathrm{CH}_{2} \tilde{\chi}^{2} \mathrm{~B}_{1}(+\mathrm{M}) \leftrightharpoons \mathrm{C}_{7} \mathrm{H}_{7} \tilde{\chi}^{2} \mathrm{E}_{2}^{\prime \prime}$ and this isomerization is consistent with much of the ratios of iso-
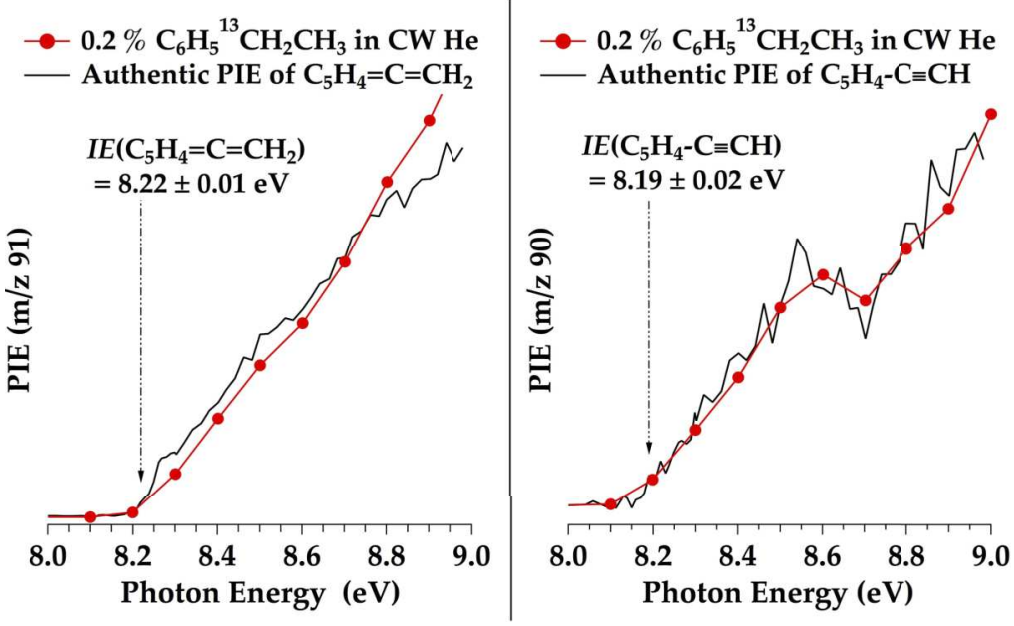

FIG. 12. PIEs confirming the identity of $\mathrm{m} / \mathrm{z} 91$ as $\mathrm{C}_{5} \mathrm{H}_{4}=\mathrm{C}=\mathrm{XH}_{2}$ and $\mathrm{m} / \mathrm{z} 90$ as $\mathrm{C}_{5} \mathrm{H}_{4}-\mathrm{C} \equiv \mathrm{XH}$. Red data points are from ethylbenzene- ${ }^{13} \mathrm{C}$ decomposition at 1500 $\mathrm{K}$ in a $\mathrm{CW}$ helium reactor. In black are previously reported ${ }^{21}$ PIEs for the two molecules with their IE's labeled on the plots. Y-axis values are scaled so that signal intensities are approximately equal. 


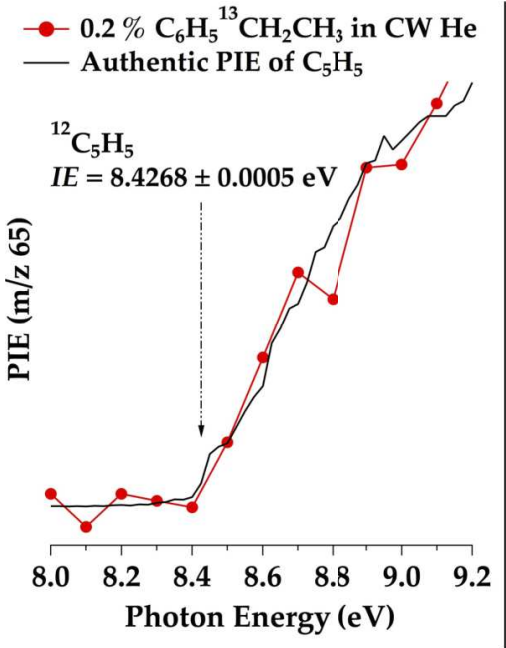

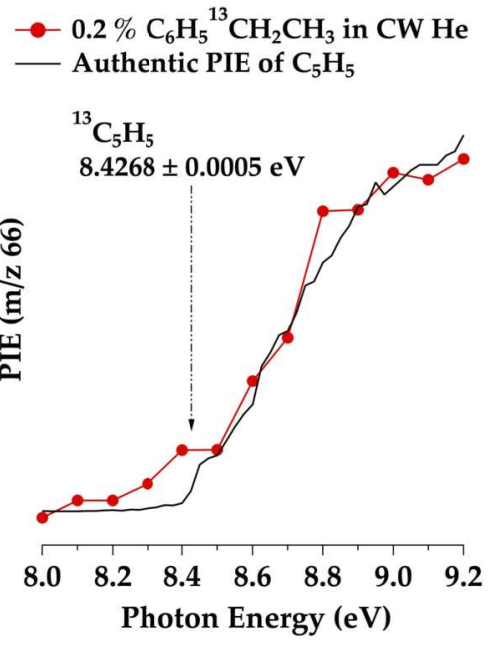

FIG. 13. PIEs confirming the identity of $\mathrm{m} / \mathrm{z} 65$ and 66 as cyclopentadienyl radical $\left(\mathrm{C}_{5} \mathrm{H}_{5}\right)$. Red data points are from ethylbenzene- ${ }^{13} \mathrm{C}$ decomposition at $1500 \mathrm{~K}$ in a $\mathrm{CW}$ He reactor. In black is the previously reported ${ }^{49} \mathrm{PIEs}$ for $\mathrm{C}_{5} \mathrm{H}_{5}$ with the IE labeled on the plots; ${ }^{13} \mathrm{C}$ substitution should have no effect on the IE. Y-axis values are scaled so that signal intensities are approximately equal. topomers detected during the $\mathrm{D} / \mathrm{H}$ and ${ }^{13} \mathrm{C}$ precursors decomposition. Because the ionization energies for both benzyl $(7.2 \mathrm{eV})$ and cycloheptatrienyl $(6.2 \mathrm{eV})$ radicals are known (Table I), PIMS can differentiate these two isotopomers. Fig. 14 shows the PIMS spectra that result from pyrolysis of $\mathrm{C}_{6} \mathrm{H}_{5} \mathrm{CD}_{2} \mathrm{Br}$ in an effusive, $\mathrm{CW}$ Ar micro-reactor at 1250 $\mathrm{K}$ taken at the SLS. The species at $\mathrm{m} / \mathrm{z} 93$ could be either benzyl $\left(\mathrm{C}_{6} \mathrm{H}_{5} \mathrm{CD}_{2}\right)$ or cycloheptatrienyl $\left(\mathrm{C}_{7} \mathrm{H}_{5} \mathrm{D}_{2}\right)$. As the synchrotron is tuned from $7.5 \mathrm{eV}$ down to $7.0 \mathrm{eV}$ and on to $6.8 \mathrm{eV}$, the $\mathrm{m} / \mathrm{z} 93$ signal collapses. The scans at $6.8 \mathrm{eV}$ and $7.0 \mathrm{eV}$ in Fig. 14 have been multiplied by a factor of 10 . We conclude that all of the $\mathrm{m} / \mathrm{z} 93$ radicals that result from pyrolysis of benzyl bromide- $\mathrm{d}_{2}$ at $1250 \mathrm{~K}$ in a CW Ar microreactor are benzyl radicals $\left(\mathrm{C}_{6} \mathrm{H}_{5} \mathrm{CD}_{2}\right)$. No cycloheptatrienyl radicals $\left(\mathrm{C}_{7} \mathrm{H}_{5} \mathrm{D}_{2}\right)$ are present in the $\mathrm{CW}$ Ar micro-reactor. It is worth noting, however, that while the isomerization, $\mathrm{C}_{6} \mathrm{H}_{5} \mathrm{CD}_{2}(+\mathrm{M}) \leftrightharpoons \mathrm{C}_{7} \mathrm{H}_{5} \mathrm{D}_{2}$, was not observed in the effusive,

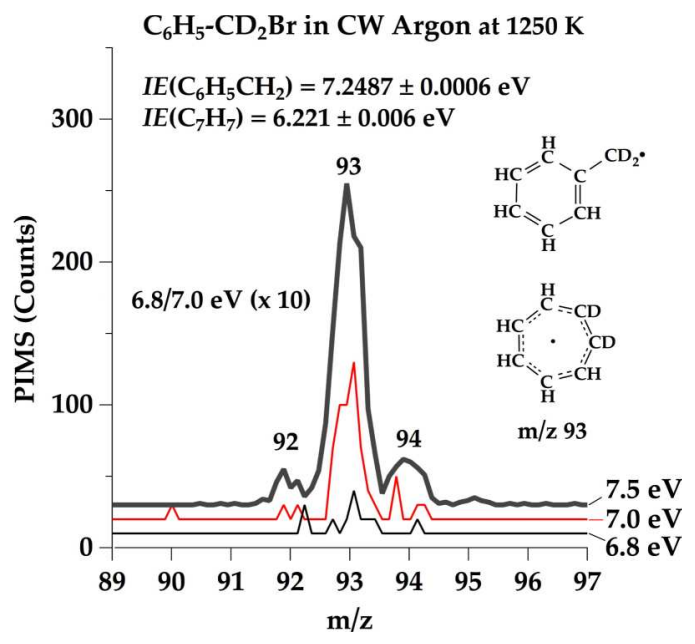

FIG. 14. PIMS for the decomposition of $\mathrm{C}_{6} \mathrm{H}_{5} \mathrm{CD}_{2} \mathrm{Br}$ at $1250 \mathrm{~K}$ in a $\mathrm{CW} \mathrm{Ar}$ reactor at the SLS. Benzyl radical $\left(\mathrm{C}_{6} \mathrm{H}_{5} \mathrm{CD}_{2}\right)$ and cycloheptatrienyl radical $\left(\mathrm{C}_{7} \mathrm{H}_{5} \mathrm{D}_{2}\right)$ have the same mass but IEs that differ by around $1 \mathrm{eV}$. The signal intensity at $\mathrm{m} / \mathrm{z} 93$ (benzyl radical- $\mathrm{d}_{2}$ ) drops off significantly at photon energies below the IE of benzyl radical, indicating that there is no population of cycloheptatrienyl radical present in this decomposition. The y-axes of the lower two photon energy scans are multiplied by 10 and are still significantly smaller than the scan at $7.5 \mathrm{eV}$, which can ionize benzyl radical.
CW Ar reactor in Switzerland, different results could be found with pulsed reactors or with the use of different carrier gas.

\section{DISCUSSION AND CONCLUSIONS}

This paper is an experimental study of the pyrolysis of the benzyl radical carried out in a set of heated microreactors. We have used both benzyl bromide and ethylbenzene as precursors of the parent species, $\mathrm{C}_{6} \mathrm{H}_{5} \mathrm{CH}_{2}$, as well as a set of isotopically labeled radicals: $\mathrm{C}_{6} \mathrm{H}_{5} \mathrm{CD}_{2}, \mathrm{C}_{6} \mathrm{D}_{5} \mathrm{CH}_{2}$, and $\mathrm{C}_{6} \mathrm{H}_{5}{ }^{13} \mathrm{CH}_{2}$. A combination of PIMS, PIE measurements, and IR spectroscopy has been used to identify the thermal decomposition products. Before making any mechanistic assessments, there are at least two difficult complications that must be resolved. These are the non-linear properties of the microreactors and the unknown pyrolysis mechanisms of the nascent metastables and radicals: fulvenallene, fulvenallenyl radical, and the cyclopentadienyl radical.

The experiments in this paper made use of four different micro-reactors: a pulsed He reactor, a pulsed Ne reactor, a $\mathrm{CW}$ $\mathrm{He}$ reactor, and a $\mathrm{CW}$ Ar reactor. All of these reactors are slightly different. Recent computational fluid dynamics (CFD) simulations ${ }^{42}$ have revealed that the heated micro-reactors are complex, non-linear devices. The chemical reactions in the micro-reactors vary exponentially with the gas temperature (which is rising) and quadratically with the pressure (which is falling). Consequently, there is only a small region of the micro-reactor in which the majority of chemical reactions occur. The size and location of the "sweet-spot" can vary dramatically with changes in reactor dimensions (diameter, length), material ( $\mathrm{SiC}$, quartz, or $\mathrm{Al}_{2} \mathrm{O}_{3}$ ), the nature of the buffer gas (He, $\mathrm{Ne}$, or $\mathrm{Ar}$ ), mass flow-rate, mode of operation (pulsed $v s$. continuous), or other factors that have not yet been anticipated. Consequently, care must be taken when comparing results from different micro-reactors.

The products $\mathrm{C}_{5} \mathrm{H}_{4}=\mathrm{C}=\mathrm{CH}_{2}, \mathrm{H}$ atom, $\mathrm{C}_{5} \mathrm{H}_{4}-\mathrm{C} \equiv \mathrm{CH}$, $\mathrm{C}_{5} \mathrm{H}_{5}, \mathrm{HCCCH}_{2}$, and $\mathrm{HC} \equiv \mathrm{CH}$ have all been detected. Consequently, we must contend with subsequent thermal cracking processes of the products: $\mathrm{C}_{5} \mathrm{H}_{4}=\mathrm{C}=\mathrm{CH}_{2}$ and the radicals $\mathrm{C}_{5} \mathrm{H}_{4}-\mathrm{C} \equiv \mathrm{CH}$ and $\mathrm{C}_{5} \mathrm{H}_{5}$. Several earlier experiments (see Fig. 5 in Ref. 26) and a computational paper ${ }^{54}$ have demonstrated that the cyclopentadienyl radical thermally decom- 
poses to propargyl and acetylene: $\mathrm{C}_{5} \mathrm{H}_{5}(+\mathrm{M}) \rightarrow \mathrm{HCCCH}_{2}$ and $\mathrm{HC} \equiv \mathrm{CH}$. The dynamics of fulvenallene pyrolysis are even more complicated. ${ }^{16,17}$ When a phthalide (1-isobenzofuranone, $\mathrm{C}_{6} \mathrm{H}_{4} \mathrm{COOCH}_{2}$ ) was used as a fulvenallene precursor, pyrolysis in a $\mathrm{CW}$ Ar micro-reactor reported decomposition of $\mathrm{C}_{5} \mathrm{H}_{4}=\mathrm{C}=\mathrm{CH}_{2}(\mathrm{~m} / \mathrm{z} 90)$ to $\mathrm{C}_{5} \mathrm{H}_{4}-\mathrm{C} \equiv \mathrm{CH}(\mathrm{m} / \mathrm{z}$ 89) and thence to the expected $\mathrm{HCCCH}_{2}(\mathrm{~m} / \mathrm{z} 39)$ and $\mathrm{HC} \equiv \mathrm{C}-\mathrm{C} \equiv \mathrm{CH}$ $(\mathrm{m} / \mathrm{z} 50)$. However, Fig. 3 in Ref. 16 also reveals the presence of $\mathrm{HC} \equiv \mathrm{CH}(\mathrm{m} / \mathrm{z} 26)$, a set of products at $\mathrm{m} / \mathrm{z}$ 63-65, as well as 76,78 . In this paper, we have also observed many of these products but we cannot tell if they result from $\mathrm{C}_{6} \mathrm{H}_{5} \mathrm{CH}_{2}$ decomposition or from $\mathrm{C}_{5} \mathrm{H}_{5}$ and $\mathrm{C}_{5} \mathrm{H}_{4}=\mathrm{C}=\mathrm{CH}_{2}$ decomposition. Until the fragmentation of fulvenallene and the cyclopentadienyl radical is properly understood, it will be difficult to confirm the products of $\mathrm{C}_{6} \mathrm{H}_{5} \mathrm{CH}_{2}$ pyrolysis.

Even with these two complexities-the non-linear nature of the reactors and the obscuring products from cyclopentadienyl and fulvenallene decomposition-there is compelling isotopic evidence that the fulvenallene-decomposition pathway in Fig. 1 is not the sole route for $\mathrm{C}_{6} \mathrm{H}_{5} \mathrm{CH}_{2}$ decomposition. The enhanced $\mathrm{D} / \mathrm{H}$ ratio on $\mathrm{C}_{5} \mathrm{H}_{5}$ observed during $\mathrm{C}_{6} \mathrm{H}_{5} \mathrm{CD}_{2} \mathrm{CD}_{3}$ decomposition (Fig. 8) reveals an unexpected incorporation of $\mathrm{D}$ into the cyclopentadienyl radical. The deuteration pattern resultant from bimolecular D-atom chemistry displayed in Fig. 9 is not present in $\mathrm{C}_{6} \mathrm{H}_{5} \mathrm{CD}_{2}$ decomposition. The presence of $\mathrm{C}_{5} \mathrm{H}_{5}(\mathrm{~m} / \mathrm{z} 65)$ predicted by Fig. 1 is dwarfed by signals at $\mathrm{m} / \mathrm{z} 66\left(\mathrm{C}_{5} \mathrm{H}_{4} \mathrm{D}\right)$ and $\mathrm{m} / \mathrm{z} 67$ $\left(\mathrm{C}_{5} \mathrm{H}_{3} \mathrm{D}_{2}\right)$. Likewise for the case of $\mathrm{C}_{6} \mathrm{H}_{5}{ }^{13} \mathrm{CH}_{2}$ in Fig. 11, intense signals for both ${ }^{12} \mathrm{C}_{5} \mathrm{H}_{5}(\mathrm{~m} / \mathrm{z} 65)$ and $\left({ }^{13} \mathrm{C}\right) \mathrm{C}_{4} \mathrm{H}_{5}(\mathrm{~m} / \mathrm{z}$ $66)$ are present. The PIE curves in Fig. 13 confirm the identity of both of these peaks as cyclopentadienyl radicals. The ${ }^{13} \mathrm{C}$ experiments in Fig. 11 also clearly show the formation of both $\mathrm{CH}_{3}(\mathrm{~m} / \mathrm{z} 15)$ and ${ }^{13} \mathrm{CH}_{3}(\mathrm{~m} / \mathrm{z} 16)$ radicals at $1500 \mathrm{~K}$ during $\mathrm{C}_{6} \mathrm{H}_{5}{ }^{13} \mathrm{CH}_{2}$ decomposition. Fig. 11 also shows clear evidence for ${ }^{12}$ benzyne (m/z 76), ${ }^{12}$ phenyl radical (m/z 77$)$, and ${ }^{12}$ benzene (m/z 78). None of these species seems to incorporate ${ }^{13} \mathrm{C}$, thus indicating that their formation is from direct decay of parent. These results are not compatible with the fulvenallene pathway predicted in Fig. 1.

The failure to detect cycloheptatrienyl radicals (Fig. 14) is puzzling. An obvious route to scramble ${ }^{13} \mathrm{C}$ into the cyclopentadienyl radical (see Fig. 11) is through the cycloheptatrienyl radical,

$$
\mathrm{C}_{6} \mathrm{H}_{5}{ }^{13} \mathrm{CH}_{2}(+\mathrm{M}) \leftrightharpoons\left({ }^{13} \mathrm{C}\right) \mathrm{C}_{6} \mathrm{H}_{7} \rightarrow \mathrm{HCCH}+\left({ }^{13} \mathrm{C}\right) \mathrm{C}_{4} \mathrm{H}_{5} .
$$

If there were a low barrier between the cycloheptatrienyl radical and its decomposition products (acetylene, cyclopentadienyl radical), there might only be a small pool of $\mathrm{C}_{7} \mathrm{H}_{7}$ radicals. Consequently, detection of $\mathrm{C}_{7} \mathrm{H}_{7}$ could be very difficult. As a result, the implications of Fig. 14 are not completely clear at this time.

\section{ACKNOWLEDGMENTS}

This paper has been strengthened by many helpful discussions with Dr. Hans Heinrich Carstensen. We would like to acknowledge support from the National Science Foundation (Nos. CHE-1112466 and CBET-1403979) for J.W.D. and G.B.E. M.A., O.K., and the Advanced Light Source are supported by the Director, Office of Science, Office of Basic Energy Sciences, of the U.S. Department of Energy under Contract No. DE-AC02-05CH11231 through the Chemical Sciences Division. M.R.N. and D.J.R. are supported by United States Department of Energy's Bioenergy Technology Office, under Contract No. DE-AC36-99GO10337 with the National Renewable Energy Laboratory. P.H. was supported by the Swiss Federal Office for Energy (BFE Contract No. 101969/152433). Some of the experimental work was carried out at the $\mathrm{x} 04 \mathrm{db}$ (VUV) beamline of the Swiss Light Source located at the Paul Scherrer Instititut (PSI).

${ }^{1}$ M. Szwarc, J. Chem. Phys. 16, 128 (1948).

${ }^{2}$ R. D. Smith, J. Phys. Chem. 83, 1553 (1979).

${ }^{3}$ D. C. Astholz, L. Brouwer, and J. Troe, Ber. Bunsenges. Phys. Chem. 85, 559 (1981).

${ }^{4}$ D. C. Astholz and J. Troe, J. Chem. Soc., Faraday Trans. 2 78, 1413 (1982).

${ }^{5}$ L. Brouwer, W. Müller-Markgraf, and J. Troe, Ber. Bunsenges. Phys. Chem. 87, 1031 (1983).

${ }^{6}$ V. S. Rao and G. B. Skinner, Proc. Combust. Inst. 21, 809 (1986).

${ }^{7}$ A. H. Laufer, J. Chem. Phys. 73, 49 (1980).

${ }^{8}$ A. H. Laufer and A. Fahr, Chem. Rev. 104, 2813 (2004).

${ }^{9}$ R. Fröchtenicht, H. Hippler, J. Troe, and J. P. Toennies, J. Photochem. Photobiol., A 80, 33 (1994).

${ }^{10}$ M. Braun-Unkhoff, P. Frank, and T. Just, Ber. Bunsenges. Phys. Chem. 94, 1417 (1990)

${ }^{11}$ R. Sivaramakrishnan, M. C. Su, and J. V. Michael, Proc. Combust. Inst. 33, 243 (2011).

12J. Jones, G. B. Bacskay, and J. C. Mackie, J. Phys. Chem. A 101, 7105 (1997).

${ }^{13}$ G. da Silva and J. W. Bozzelli, J. Phys. Chem. A 113, 6979 (2009).

${ }^{14}$ C. Cavallotti, M. Derudi, and R. Rota, Proc. Combust. Inst. 32, 115 (2009).

${ }^{15}$ G. da Silva, J. Phys. Chem. A 114, 6861 (2010).

${ }^{16}$ G. da Silva, A. J. Trevitt, M. Steinbauer, and P. Hemberger, Chem. Phys. Lett. 517, 144 (2011).

${ }^{17}$ G. da Silva and A. J. Trevitt, Phys. Chem. Chem. Phys. 13, 8940 (2011).

${ }^{18}$ D. Polino and C. Cavallotti, J. Phys. Chem. A 115, 10281 (2011).

${ }^{19}$ D. Polino, A. Famulari, and C. Cavallotti, J. Phys. Chem. A 115, 7928 (2011).

${ }^{20}$ M. Steinbauer, P. Hemberger, I. Fischer, and A. Bodi, ChemPhysChem 12, 1795 (2011).

${ }^{21}$ J. Giegerich and I. Fischer, Phys. Chem. Chem. Phys. 15, 13162 (2013).

${ }^{22}$ K. H. Fischer, P. Hemberger, A. Bodi, and I. Fischer, Beilstein J. Org. Chem. 9, 681 (2013).

${ }^{23}$ A. V. Friderichsen, E.-J. Shin, R. J. Evans, M. R. Nimlos, D. C. Dayton, and G. B. Ellison, Fuel 80, 1747 (2001).

${ }^{24}$ A. Vasiliou, M. R. Nimlos, J. W. Daily, and G. B. Ellison, J. Phys. Chem. A 113, 8540 (2009).

${ }^{25}$ A. K. Vasiliou, J. H. Kim, T. K. Ormond, K. M. Piech, K. N. Urness, A. M. Scheer, D. J. Robichaud, C. Mukarakate, M. R. Nimlos, J. W. Daily, Q. Guan, H.-H. Carstensen, and G. B. Ellison, J. Chem. Phys. 139, 104310 (2013).

${ }^{26}$ A. M. Scheer, C. Mukarakate, D. J. Robichaud, M. R. Nimlos, H.-H. Carstensen, and G. B. Ellison, J. Chem. Phys. 136, 044309 (2012).

${ }^{27}$ A. M. Scheer, "Thermal decomposition mechanisms of lignin model compounds: From phenol to vanillin," Ph.D. thesis (University of Colorado, Boulder, Colorado, 2011).

${ }^{28}$ T. K. Ormond, A. M. Scheer, M. R. Nimlos, D. J. Robichaud, T. P. Troy, M. Ahmed, J. W. Daily, J. F. Stanton, and G. B. Ellison, "Pyrolysis of cyclopentadienone: Mechanistic insights from a direct measurement of product branching ratios," J. Phys. Chem. A (in press).

${ }^{29}$ A. M. Scheer, C. Mukarakate, D. J. Robichaud, G. B. Ellison, and M. R. Nimlos, J. Phys. Chem. A 114, 9043 (2010).

${ }^{30}$ X. Zhang, A. V. Friderichsen, S. Nandi, G. B. Ellison, D. E. David, J. T. McKinnon, T. G. Lindeman, D. C. Dayton, and M. R. Nimlos, Rev. Sci. Instrum. 74, 3077 (2003).

${ }^{31}$ N. P. Lockyer and J. C. Vickerman, Laser Chem. 17, 139 (1997).

${ }^{32}$ J. Boyle and L. Pfefferle, J. Phys. Chem. 94, 3336 (1990).

${ }^{33}$ R. E. Bandy, C. Lakshminarayan, R. K. Frost, and T. S. Zwier, J. Chem. Phys. 98, 5362 (1993).

${ }^{34}$ M. Johnson, A. Bodi, L. Schulz, and T. Gerber, Nucl. Instrum. Methods Phys. Res., Sect. A 610, 597 (2009). 
${ }^{35}$ A. Bodi, M. Johnson, T. Gerber, Z. Gengeliczki, B. Sztaray, and T. Baer, Rev. Sci. Instrum. 80, 034101 (2009).

${ }^{36}$ See supplementary material at http://dx.doi.org/10.1063/1.4906156 for matrix IR frequencies for many of the molecules assigned in this study as well as the decomposition pathways for several isotopically labeled benzyl radicals.

${ }^{37}$ P. Chen, S. D. Colson, W. A. Chupka, and J. A. Berson, J. Phys. Chem. 90, 2319 (1986).

${ }^{38}$ D. W. Kohn, H. Clauberg, and P. Chen, Rev. Sci. Instrum. 63, 4003 (1992).

${ }^{39}$ J. A. Blush, H. Clauberg, D. W. Kohn, D. W. Minsek, X. Zhang, and P. Chen, Acc. Chem. Res. 25, 385 (1992).

${ }^{40} \mathrm{P}$. Chen, in Unimolecular Bimolecular Ion-Molecule Reaction Dynamics, edited by C. Y. Ng, T. Baer, and I. Powis (John Wiley, Cambridge, UK, 1994), p. 371.

${ }^{41}$ H. W. Rohrs, C. T. Wickham-Jones, D. Berry, G. B. Ellison, and B. M. Argrow, Rev. Sci. Instrum. 66, 2430 (1995).

${ }^{42}$ Q. Guan, K. N. Urness, T. K. Ormond, D. E. David, G. B. Ellison, and J. W. Daily, Int. Rev. Phys. Chem. 33, 447 (2014).

${ }^{43}$ C. L. Angell, J. Mol. Struct. 10, 265 (1971).

${ }^{44}$ E. B. Jochnowitz, X. Zhang, M. R. Nimlos, M. E. Varner, J. F. Stanton, and G. B. Ellison, J. Phys. Chem. A 109, 3812 (2005).

${ }^{45}$ E. G. Baskir, A. K. Maltsev, V. A. Korolev, V. N. Khabashesku, and O. M. Nefedov, Russ. Chem. Bull. 42, 1438 (1993).

${ }^{46}$ B. E. Applegate, A. J. Bezant, and T. A. Miller, J. Chem. Phys. 114, 4869 (2001).

${ }^{47}$ X. Zhang and P. Chen, J. Am. Chem. Soc. 114, 3147 (1992).

${ }^{48}$ H. J. Wörner and F. Merkt, J. Chem. Phys. 127, 034303 (2007).

${ }^{49}$ J. D. Savee, private communication (2014).

${ }^{50}$ A. Vasiliou, K. M. Piech, X. Zhang, M. R. Nimlos, M. Ahmed, A. Golan, O. Kostko, D. L. Osborn, J. W. Daily, J. F. Stanton, and G. B. Ellison, J. Chem. Phys. 135, 014306 (2011).

${ }^{51}$ K. N. Urness, Q. Guan, A. Golan, J. W. Daily, M. R. Nimlos, J. F. Stanton, M. Ahmed, and G. B. Ellison, J. Chem. Phys. 139, 124305 (2013).
${ }^{52}$ D. M. Golden, Int. J. Chem. Kinet. 40, 310-319 (2008).

${ }^{53}$ L. D. Brouwer, W. Müller-Markgraf, and J. Troe, J. Phys. Chem. 92, 4905 (1988).

${ }^{54}$ L. V. Moskaleva and M. C. Lin, J. Comput. Chem. 21, 415 (2000).

${ }^{55}$ F. A. Houle and J. L. Beauchamp, J. Am. Chem. Soc. 100, 3290 (1978).

${ }^{56}$ G. C. Eiden, F. Weinhold, and J. C. Weisshaar, J. Chem. Phys. 95, 8665 (1991).

${ }^{57}$ J. B. Pedley, R. D. Naylor, and S. P. Kirby, in Thermochemistry of Organic Compounds, 2nd ed. (Chapman and Hall, New York, 1986).

${ }^{58}$ G. B. Ellison, G. E. Davico, V. M. Bierbaum, and C. H. DePuy, Int. J. Mass Spectrom. Ion Phys. 156, 109 (1996).

${ }^{59}$ R. F. Gunion, M. K. Gilles, M. L. Polak, and W. C. Lineberger, Int. J. Mass Spectrom. Ion Phys. 117, 601 (1992).

${ }^{60}$ R. D. Johnson, J. Chem. Phys. 95, 7108 (1991).

${ }^{61}$ J. C. Traeger and R. G. McLoughlin, J. Am. Chem. Soc. 99, 7351 (1977).

${ }^{62}$ T. Ichino, S. W. Wren, K. M. Vogelhuber, A. J. Gianola, W. C. Lineberger, and J. F. Stanton, J. Chem. Phys. 129, 084310 (2008).

${ }^{63}$ J. C. Poutsma, J. J. Nash, J. A. Paulino, and R. R. Squires, J. Am. Chem. Soc. 119, 4686 (1997).

${ }^{64}$ R. A. Seburg, B. T. Hill, and R. R. Squires, J. Chem. Soc., Perkin Trans. 2 1999, 2249.

${ }^{65}$ J. A. Blush, P. Chen, R. T. Wiedmann, and M. G. White, J. Chem. Phys. 98 , 3557 (1993).

${ }^{66}$ S. T. Pratt, P. M. Dehmer, and J. L. Dehmer, J. Chem. Phys. 99, 6233 (1993).

${ }^{67}$ H. Gao, Y. T. Xu, L. Yang, C. S. Lam, H. L. Wang, J. A. Zhou, and C. Y. Ng, J. Chem. Phys. 135, 224304 (2011).

${ }^{68}$ V. Butcher, M. L. Costa, J. M. Dyke, A. R. Ellis, and A. Morris, Chem. Phys. 115, 261 (1987).

${ }^{69}$ S. Sato, T. Kojima, K. Byodo, H. Shinohara, S. Yanagihara, and K. Kimura, J. Electron Spectrosc. Relat. Phenom. 112, 247 (2000).

${ }^{70}$ T. Baer, J. C. Morrow, J. D. Shao, and S. Olesik, J. Am. Chem. Soc. 110, 5633 (1988). 